\author{
GRASP \\ by \\ Rosemary Cann
}

A thesis submitted to Victoria University of Wellington in fulfilment of the research requirements of the degree of Master of Arts in Creative Writing.

Victoria University of Wellington 

Music.

EXT. CANTERBURY FIELDS. - MIDDAY.

RUCHIKA's face (21, tidy, curvaceous, quiet) under the falling water of a gigantic irrigation sprinkler. Her hair is wet and there is love in her eyes.

A wide smile as the water descends.

\section{FLIPBOOK PAGE SEQUENCE.}

A hand-drawn flipbook image, sketched on the bottom corner of a thick novel, being flicked through by a hand in a white glove. The image depicts a pair of hands leaking liquid from each fingertip. The liquid pools and drops fall, hitting a liquid surface below and reverberating in outward circles, forming little fish-like forms that swim around and leap from the liquid cheerfully.

INT. FAMILY BATHROOM, CANTERBURY. - EVENING.

CAROSIN's hands leak navy blue ink from the fingertips, held above the bath water.

EXT. DAIRY, CANTERBURY. - MID-MORNING .

GEOFFREY (13, keen and excitable) squints in the bright sun. A vein travelling across his forehead and temple stands out bright through his pale skin. One of his eyes has a pale blue, clouded iris.

INT. ARTIST STUDIO, KUALA LUMPUR. - EVENING.

A hand, sweeping across a canvas and leaving crimson trails from each fingertip.

EXT. CANTERBURY FIELDS. - SUNRISE.

A view of BETTY, a majestic white horse, close up, face to face with us.

FLIPBOOK PAGE SEQUENCE.

A hand-drawn flipbook image, on thick artist's paper, showing a hand gently sliding an engagement ring onto another person's wedding ring finger. They hold hands, and their arms 
swing to and fro, further away from and closer to the viewer in turn.

EXT. MOTEL CARPARK, CANTERBURY - - DAWN.

Geoffrey sits atop Betty, in a Motel carpark. He is wearing pyjamas, a coat, and a pair of shoes with the laces undone. He smiles groggily.

FLIPBOOK PAGE SEQUENCE.

A hand-drawn flipbook, in a small notebook, of ZIKRI's face (23, attentive, a little scruffy, gangly tall). He smiles and pulls silly faces.

INT. 4 X 4 FRONT SEAT, CANTERBURY FIELDS. - MID-MORNING.

Carosin's smile. The small overlap between her two front teeth. She raises a hand to her mouth, self-conscious.

INT. OFFICE EMPLOYEE LOUNGE, KUALA LUMPUR. - MORNING.

A white-gloved hand fanning up the pages of a newspaper from the bottom. The image shows a bird's progression, it's form flying across the page.

INT. CAROSIN'S LIVING ROOM, CANTERBURY. - NIGHT.

Ruchika, laughing, hides her face in her hands. A small sweeping curl, the shape of a whirlpool, in Ruchika's hair, at the base of her hairline.

INT. MOTEL KITCHENETTE, CANTERBURY • - EVENING.

The hissing sound of frying meat. White tiles with spattering droplets of hot fat spitting up from the substance cooking below.

The title against the white tiles:

GRASP

Carosin (19, strident, athletic, snarky) stares down at the stove.

She exhales through her apparent discomfort and closes her eyes. 
INT. FAMILY BATHROOM, CANTERBURY. - EARLY EVENING.

The sound of knocking at the door. A hand, dangling over the edge of a grand white bath, twitches as Carosin wakes. A droplet of diluted blue ink dangles from the tip of the index finger. There are universes in the swirling liquid. The drop splashes into blue sunflower on white tile as it hits the floor.

Yep.

\section{CAROSIN}

Carosin wipes a hand over her face, waking up properly. She leaves a pale trace of blue across her complexion.

Carosin's hands leak blue ink from each fingertip as she looks down at them. She scrunches her eyes closed tight.

She pulls her head under the water.

She stays underwater and remains still, trying to keep all of the air in her tense mouth. She opens her eyes with the strain.

INT. OFFICE, KUALA LUMPUR. - MORNING.

Ruchika, a small blue and white pansy neatly tucked into one of the pins of her hijab, looks to a list of job vacancies on one monitor and then to a list of names on the other. The logo in the corner of each screen reads 'Fulfilling Careers Kuala Lumpur'.

She looks back and forth sharply, frustrated. Her whitegloved hand sits on the mouse. She is anxious.

Her boss, JAIYANA (34, very short, skirt suit and sunglasses), passes by Ruchika's desk. Ruchika goes to ask for her help, even raising a hand slightly. Jaiyana blows straight past.

Ruchika, an expression of bored outrage.

Jaiyana's power stride in her restrictive knee-length skirt.

EXT. LARGE MANOR HOUSE, CANTERBURY. - NIGHT.

Carosin waddles, pulling her tight pink satin dress down with one white-gloved hand. Uncomfortable, Carosin walks through crowds of dolled-up young men and women. The champagne flows and the crowds drunkenly mingle at this upper-class function. Carosin's make-up is flawless but her hair is still limp and 
damp from the bath. She nervously sips at her drink and pushes through the laughing crowd.

Navy bow tie. Silver cravat. Deep red braces.

As she squeezes between two very tall, buff private school boys in Hallensteins suits, she is suddenly confronted by a grinning, tipsy, CHERYL SAMSON (53, deep red hair and bright lime green eye make-up) •

\section{Carosin Thomas!}

\section{CHERYL}

Carosin holds a hand up to wave awkwardly, which cheryl grabs. She strides through the party with Carosin in tow, both of their hands slightly aloft as if it is a victory lap.

Cheryl turns to Carosin suddenly, stopping sharply. Carosin bumps into her with force, but Cheryl doesn't seem to notice. Cheryl leans in to stage-whisper faux-conspiratorially, but is halted by the smell of Carosin's glass -

\section{MRS. SAMSON}

My lord is that rum and coke! How wondrously bogan of you...

Carosin looks past Cheryl and sees JOHN (21, dashing and handsome in a Weetbix marathon sort of way) sitting by an outdoor fire with a very slim, beautiful woman. He is totally enraptured with her. Cheryl nods a little towards him, winking. Carosin's enquiring expression. Cheryl does a funny little pointy click routine. Embarrassing.

Carosin strides past Cheryl and towards John.

Cheryl, impressed with Carosin's willingness, watches her for a few steps, nods to herself, and turns back to the party, literally patting herself on the back.

Carosin halts by John, the sounds of the party wash over them. John takes a second to look up, then smiles warmly at her. He shuffles along enthusiastically for Carosin to sit down, accidentally shoving the girl he was previously talking to, MONIKA (18, elegant), causing her to spill her wine on her dress. John looks between them, startled. Monika, disgruntled, leaves to clean herself up. John turns his whole body towards Carosin.

INT. OFFICE EMPLOYEE LOUNGE, KUALA LUMPUR. - MIDDAY.

Ruchika sits on the sofa, eating a sandwich and doodling on the corner of a newspaper. The headline reads 'HOMOSEXUAL BAR SHUT DOWN FOLLOWING CRIMINAL BEHAVIOUR.' 
Ruchika frowns and draws the last in a sequence of flying birds. She fans up the pages and connects her thumb and forefinger to make a circle, which she drags across the sequence of birds.

Her face with one eye closed, focusing.

Her phone rings. Flustered, she quickly folds the paper, speed chews and swallows, coughing a little, fans the chokingtears back from her eyes and answers the phone with an abstract croak. The voice on the phone speaks in Bahasa Melayu, or, in English, 'Malay'.

JAIYANA (ON PHONE, BAHASA MELAYU)

It's been 15 minutes Miss Mahatir.

Somewhat outraged, Ruchika leans to peer through several glass walls and doors to see Jaiyana on the phone in her office. Jaiyana hangs up.

INT. INTIMATE RESTAURANT, KUALA LUMPUR. - EVENING.

The same expression of outrage on Ruchika's face.

Zikri sits across the table from her, chuckling at her anger. She shakes her head. 'Of course I'm getting annoyed over nothing.' She relaxes visibly, making a funny face at him. She reaches across the table and holds zikri's hand gently in hers, her gloves still on. He is delighted. She is adoring.

INT. RUCHIKA'S BEDROOM, KUALA LUMPUR. - NIGHT.

A hand-drawn flipbook in a small notebook. The image shows Zikri smiling and pulling silly faces. Ruchika smiles down at it, touches her bound fingertips to the final image, and then to her lips.

INT. CAROSIN'S KITCHEN, CANTERBURY. - MORNING.

RODNEY (53, clean-shaven, uncomfortable), sorts through the mail, alone at the breakfast table. He slides two envelopes into his breast pocket.

SANDRA (45, zesty, particular) on the other side of the kitchen, pours a dash of whiskey into her protein shake. She puts the whiskey away and shakes her drink container vigorously.

In the entrance to the kitchen, perfectly in the middle of her two parents, and unseen, stands Carosin. 
She takes several strides back and then noisily enters. Both parents fix their faces to welcome her.

RODNEY

Good morning sweetness.

Carosin!

SANDRA

She sees Carosin's loose clothing and bare hands.

SANDRA

Would you bind your hands before

breakfast please? We don't want any

muck with the food.

Geoffrey enters and rolls his eyes at their display.

CAROSIN

It's not like it stains, Sandra.

Frowning at not being called Mum, Sandra sharpens.

SANDRA

Just because it doesn't last

doesn't mean it's not unsightly,

sweetie.

Rodney attempts to lighten the mood -

RODNEY

Your mother's all about looks Caro!

He gives Geoffrey a blokey nudge, winking and laughing.

RODNEY

That's why she went for me ay son!

SANDRA

No darling I married you for your money.

Rodney tries to laugh it off, clearly wounded. Sandra smiles and crosses the room to kiss him on the cheek. They both smile at Geoffrey and Carosin. A moment of awkward togetherness. Sandra looks about and finds an excuse to walk away.

RODNEY

Right kids... off to school Geoff!

We're not paying four thousand

dollars a year for this level of

banter. 
He scruffs Geoffrey's hair as the pair move towards the front door. The blue vein is revealed again.

Carosin gives Rodney a sympathetic smile, he returns it.

\section{Dad! Your keys.}

$$
\text { CAROSIN }
$$

She tosses Rodney his keys from the table, he catches them, smiling his thanks and making a 'Silly me' gesture.

The front door closes, Carosin sighs.

INT. LIZZY'S BEDROOM, CANTERBURY. - AFTERNOON.

A breathy exhale from LIZZY (27, athletic build, confident) as Carosin kisses down her body. Carosin's right hand, with bound fingertips, holds Lizzy's hands above her head. She moves her hand slightly to cover Lizzy's wedding band. Carosin speaks softly, intimately -

\section{CAROSIN}

What do you want?

\section{LIZZY}

Do what you want.

Carosin is annoyed, they share a glance. The mood falters.

EXT. CANTERBURY FIELDS. - DUSK.

Lizzy rides a black horse, with Carosin sat behind her, across a paddock, towards Betty, who is grazing peacefully. Carosin dismounts smoothly and without hesitation. She goes to Betty and mutters to her, kissing her on the nose.

\section{LIZZY}

I'll see you tomorrow.

I have to train.

CAROSIN

Lizzy looks pissed. Carosin turns, gives a deliberate attempt at a warmer smile. Lizzy returns it and trots away.

Carosin brushes Betty's nose and cheek and, tenderly-

CAROSIN

Don't worry Betty, I only love you. 
INT. PRIYA AND AISAR'S APARTMENT, KUALA LUMPUR. - MORNING.

Ruchika sits on the couch beside her mother, PRIYA (43, chubby, modest, proud, gentle), doing an intricate henna design up her mother's arm. They share a long glance. Priya smiles a small smile, and goes back to watching her stories. She gazes.

EXT. HORSE BARN, CANTERBURY - - DUSK.

Carosin's face, gazing. She sits on a fence looking out into the countryside, Betty nearby, chewing at grass. Carosin brings a spliff to her lips.

CAROSIN

Chewing the grass. Shooting the

breeze.

Betty looks up at her.

Carosin mimes shooting into the sky as she looks at Betty. She closes one eye, imitating a caricature of an old-time Sheriff.

Betty blinks.

\section{What?}

CAROSIN

Betty looks away again. She trots towards the barn. Carosin looks back to the view. Betty clomps past rusted blades and hunting knives affixed to the wall of the barn as she enters.

$$
\text { TOo right. CAROSIN }
$$

Carosin sits soaking in the dusk for a long time. The light is blue, she finds herself feeling hollow. She closes her eyes, remembers...

Lizzy's mouth on her neck, kissing her.

Lizzy's fingers scraping down her back.

Lizzy's mouth, giving her a love bite on her inner wrist.

Carosin takes another drag of the spliff. She takes it out of her mouth, and presses the glowing orange end into the place where Lizzy's mouth was. Searing pain. Her expression is numb.

It begins to rain. 
INT. ARTIST STUDIO, KUALA LUMPUR. - EVENING.

A glowing bulb, bare, in the ceiling above a largely vacant, aging studio space. Booming music in Ruchika's headphones, her forehead sweating with exertion. She paints with her bare hands, henna gracefully soaring across the canvas. She writes in arabic characters, sweeping letters.

With her power of her whole body, she sweeps her thumb roughly right across a canvas. She leaves a deep red henna trail in the wake of her fingertips.

She steps back, panting and smiling.

The sounds of her breath.

INT. CAROSIN'S BEDROOM, CANTERBURY. - VERY EARLY MORNING.

Eyes opening with a start. A sharp inhaled breath.

The clock reads 4:00. She hops out of bed and begins straight away to dress herself in her equestrian gear.

INT. CAROSIN'S BATHROOM, CANTERBURY. - VERY EARLY MORNING.

Carosin arches her back to apply cream to a deep red, weeping sore on her lower back. Her riding gear has rubbed raw where the waist band meets soft skin.

She winces, her breath catching in her throat. She raises her hands in front of her and clenches her fists tight, gritting her teeth through the pain.

Her arms are littered with sporadic, perfectly circular scars.

INT. ARTIST STUDIO, KUALA LUMPUR. - EVENING.

Ruchika kneels over a canvas. She lets saliva drip in a long thread from her mouth into a pot holding small flecks of gold leaf. She stops, wipes her chin and mixes the materials together hastily with her rubber-gloved index finger. She carefully tips the pile of gold paste into a circle on the canvas.

Ruchika's face scrunched up. Ruchika, sat in the lotus position, with an upturned foot and a craft knife in hand. She punctures the skin on the base of her big toe. We see her toe being pressed to the canvas on the floor. Ruchika's face in pain, looking away. Ruchika looking down at the canvas. She jerks her head to the side. 'Alright'. 
Ruchika running on the spot full speed. The plaster around her big toe suffers under the friction. Panting, Ruchika throws herself down and, leaning over the canvas, tries to aim a drop of sweat which dangles from the end of her nose. The droplet falls onto a small spot of golden ink. Splash.

Ruchika unpeeling a plaster on her thumb, massaging the tip to softly leak henna. She dips her thumb into glass of water. Spirals of deep red henna emanate and hang in the liquid. Her thumb being placed to the canvas and swept in a wide arch. The momentum flicks small rays out from the semi-circular arch.

A watery sunrise.

EXT. CANTERBURY FIELDS. - DAWN.

Cold and calm, the sun creeps up. Betty gallops under Carosin's skilled guidance. She leans in to the stride of the horse, determined and focused. Her expression changes to exhilaration when she lets out a whoop as the pair jump a high combination fence.

Carosin dismounts elegantly, breathing heavily, red-cheeked. She smiles, facing Betty, takes a step back and salutes. Betty raises a leg. Carosin laughs, taking Betty's reins and placing her forehead against Betty's muzzle, one gloved hand on each of the horse's cheeks.

Carosin leans her head against Betty's nose and they exhale. Carosin squeezes her eyes shut tight for a second. When she opens them again, she is gazing right at Betty.

The horse blinks, deep brown iris and long eyelashes.

INT. RUCHIKA'S LOUNGE, KUALA LUMPUR. - MID-AFTERNOON.

Long curves flicking out from an ornate flower pattern drawn in henna. Ruchika sits beside her neighbor, DOREEN (21, vivacious and energetic), who is reclining in a bright, draping shirt and a long tie dye dress.

They sit in a dishevelled, bohemian inner-city apartment. It is cramped but charming and full of colour and artwork. Doreen's face is covered in a thick green face mask, her eyes cucumbered. She mumbles along tunelessly to the radio playing faintly in the background, as it plays a Gwendolyn Prair song. 


\section{DOREEN}

Of course! I miss my parents and the celebrations and the support and the community, but I know who I am, and a system that rejects me for something I can't change is not a system I want to be part of.

Ruchika looks at her watch, and rushes to the kitchen sink.

Oh no.

\section{RUCHIKA}

Doreen removes the cucumbers and looks to Ruchika, as Ruchika shakes the moisture off her hands.

\section{DOREEN \\ I needed you to do this today.}

She wiggles her fingers and shows the beautiful henna.

Ruchika puts on her white gloves, her expression quizzical.

DOREEN

Just to check if you're good enough

to do my bridal Mehndi that's all.

Ruchika pauses.

\section{Doreen...?}

\section{RUCHIKA}

Her mouth agape. A smile. Doreen nods.

Letting out a joyful noise, Ruchika crosses back to Doreen and embraces her tightly. Doreen grins, but keeps her freshly hennaed arms extended and out of harm's way.

INT. HALLWAY OUTSIDE RUCHIKA'S APARTMENT, KL. - AFTERNOON.

Ruchika unlocks the next door along and enters. She tries to sneak, quietly moving around the space changing her jewelry and shoes. She is utterly silent.

Just as she goes to leave, the door to AABIDAH's bedroom swings open. Aabidah (21, a silent mover, sombre yet sharp) stands silently and stares. Ruchika smiles, Aabidah does not.

INT. PRIYA AND AISAR'S APARTMENT, KL. - MID-MORNING.

Priya sits with a plate of snacks perched on her plump belly, watching a Malaysian talent quest, enraptured. 
Four bricks pass through the windows to her right, one at a time and in slow motion. They shatter the glass of the large windows. The sound is overwhelming. Chaos.

One bounces, hitting a pile of shoes.

One smashes an ornamental vase on the other side of the room.

One bounces and hits the middle of an ornamental book case, knocking a beautifully decorated Qu'ran from it's display stand.

The final brick bounces off the arm of the sofa and flies in front of Priya's face, just catching the tip of her nose. Snap.

The Qu'ran hits the floor in real time. Silence.

Priya's shaking breath and panicked eyes. Her nose streaming blood, she crouches in front of the sofa and looks to the smashed windows.

\section{Kafir!}

HOSTILE VOICE (O.S.)

Priya, now crying, looks around, picks up a tea towel to staunch her nose's bleeding. She holds up the TV remote like a baseball bat, terrified.

She leans over the beautiful orange fabric of the coffee table cloth as she stands, shaking. A drop of blood falls down onto the peach satin.

EXT. KUALA LUMPUR SKYLINE. - SUNSET.

A blood sun sits low in the amber sky, over the cityscape of Kuala Lumpur. Fire.

INT. ARTIST STUDIO, KUALA LUMPUR. - EARLY MORNING.

Blue and white safety tape in a pile, the excess of a strip pulled tight across a smashed window.

Shards .

The breeze gently shifts the tape. The space is silent. Still.

Ruchika sits curled up in the middle of the floor, looking at the studio wall, over her tucked in knees. 
Her canvases, almost twenty of them, all in crimson and blue and gold and brown. All slashed.

Her eyes are red raw. She buries her head back into her knees.

A low roar from her mouth, into her knees, and then out into the world.

She stares, she is still, and she howls.

The sound builds into the yelling of hundreds of voices.

EXT. CANTERBURY SHOW GROUNDS - - MIDDAY .

Carosin is stood atop Betty's saddle, bowing to the crowd on three different sides as they go wild congratulating her. The three judges hold a 9, a 9, and a 10. Carosin's expression is pure joy, she drops back into the saddle. The sound of deep breaths.

INT. BARN, CANTERBURY COMPETITION. - MIDDAY.

\section{Well done my baby .}

Carosin places a gloved hand on each side of Betty's face, and kisses her cheek. She whispers -

$$
\begin{aligned}
& \text { CAROSIN } \\
& \text { I'm so proud of us. }
\end{aligned}
$$

Exhilarated, she squeals and breaks into a freestyle victory dance routine, singing in staccato phrases-

\section{CAROSIN}

We - are - go -nna be- / the -best -

team - they - see - / and - win -

horse - of the year - / and rider

of the yea-ahhh!

Betty whinnies.

Carosin's riding boots kick up swirls of dust.

INT. PRIYA AND AISAR'S APARTMENT, KL. - NIGHT.

AISAR (45, wiry, bespectacled, serious) slams his fist down onto the table. His mouth is tight, his work clothes dishevelled. Priya and Ruchika also sit at the table. They each have a plate in front of them but none of them eat. 
Priya's nose is bandaged and reset. Congealed blood in her nostrils. She sniffs, winces.

Priya places a hand atop Aisar's, gently unfurling his fist and placing his hand flat on the table. He relaxes slightly.

AISAR (BAHASA MELAYU)

You don't seem to understand what

you have done.

Priya withdraws her hand. Ruchika's face, ashamed and sullen.

AISAR (BAHASA MELAYU)

I asked you not to use the holy

text. I asked you to be respectful.

Ruchika goes to speak, Aisar slams his fist down again.

AISAR (BAHASA MELAYU)

IT IS HERESY RUCHIKA!

He attempts to calm himself.

AISAR (BAHASA MELAYU)

You have put us all in danger. We

have let you practice this 'hobby'

long enough. You are a worker, you

will be a wife, that is more than

enough.

You need to go out of this poison

city and be safe, peaceful, until

the police find who has done this.

Ruchika silently nods. Her mind fights, her voice cannot.

AISAR (BAHASA MELAYU)

You'll go to Sarawak, stay with

Manahil.

Ruchika panics.

$$
\begin{aligned}
& \text { RUCHIKA (BAHASA MELAYU) } \\
& \text { I... If I have to go away, } \\
& \text { I'd like to go to Aunty Mena. }
\end{aligned}
$$

Aisar and Priya are surprised by her conviction, but after a moment and a glance to each other, the nod, exhausted.

$$
\text { I'll book it tonight. }
$$

I can-

RUCHIKA 
Aisar waves her away. Priya gives her a stern look. They return to their cold food.

INT. AEROPLANE CABIN. - DAWN.

A cold, untouched aeroplane meal.

Ruchika blinks, waking from a shallow sleep. She looks out the window and white clouds reflect in her pupils.

She looks straight forward, inquisitive.

She calmly unbuckles her seat belt, walks to the emergency exit, passing easily by the passengers seated there. She opens the hatch and throws it out of the opening. With an arm on each side of the doorway, she leans out and screams into oblivion.

She remains there, silently screaming, the wind ripping her voice away from her, for a long moment.

The white noise crescendos into the roar of the aeroplane cabin's interior.

She blinks, frightened by her own imaginings, and looks at those around her, as if to check they don't know what she was envisioning.

INT. CAROSIN'S KITCHEN, CANTERBURY. - MIDDAY.

Carosin enters the kitchen. Sandra and Geoffrey turn in the way that means they've definitely just been talking about her.

Carosin raises her eyebrows, 'What guys?'

They share a nervous glance.

CUT TO:

Carosin, Geoffrey, Sandra and Rodney are sat around the kitchen table, bills and letters spread out in a mess.

Carosin is silent. Shocked. She shakes her head.

CAROSIN

This isn't fair. I have trained -

Her parents share a glance. 
CAROSIN

- every morning, every evening. I

put off uni for this, for you. And

now what? I can't compete?!

SANDRA

They've frozen everything. We

simply can't register you.

CAROSIN

I'll use my own money.

Rodney shakes his head.

RODNEY

It's thousands Caro, we owe thousands.

CAROSIN

But you're still going?

RODNEY

It's still important that we match

the horse-

CAROSIN

Betty. Her name is Betty.

RODNEY

Betty is, a valuable asset. If we

can find her a good breeding

investor we can solve-

CAROSIN

It shouldn't need solving.

She walks to the sink, pouring a glass of water from the tap. Her back still turned to them, she spits out her words -

CAROSIN

I can't believe you've done this to me -

RODNEY

It's happening to all of us. The

hor- Betty, was always an

investment.

Carosin sips her water and approaches the table calmly. She pauses behind her chair and coldly speaks.

CAROSIN

I was invested. 
She pours the water over his documents and as he stands, furious, she holds his gaze. He pauses, caught in her rage, and softly wipes his mouth with the back of his wet hand.

Carosin walks away from the table. Rodney begins to sort through the sodden papers, muttering but audible -

\section{RODNEY \\ Fucking mess. Little bitch.}

Geoffrey winces. Carosin, without looking back, throws her now empty glass against the hallway wall. It smashes.

RODNEY

WE GET IT!

Shards litter the ground, Carosin keeps walking.

EXT. LIFESTYLE BLOCK, CANTERBURY. - MID-MORNING.

The glint of the bright sun reflecting off the back of a vintage car.

Ruchika's head, black hijab stark against blue canterbury sky.

She stands in the driveway, suitcase beside her, staring up at the house. It is modern, sleek.

Aunty Mena and Uncle Pascal get out of the car, stationary behind her. They are dressed up as if they're about to attend the races. Mena wears her hair out and full facial make-up, Pascal wears short slacks with bright white socks and boat shoes, and a blue sweater knotted around his neck, golfer style. The pair, cheering, pull Ruchika into a hug, exclaiming simultaneously, leading her into the house -

PASCAL

My little Roosh you're going to

love the fresh Canterbury air!

MENA

Little peanut you look so stressed! It'll be good for your skin-

PASCAL

Come in we've got terrine, terrine and crackers!

MENA

- let alone your health! The air here can't help but be one hundred percent pure! 
PASCAL

Are you vegetarian? Surely not

Rooshy it's not the way at all-

MENA

You're all breasts Rooshy I can't

believe it!

PASCAL

And how is Zikri? Handsome Zikri!

Pascal plops the suitcase down in the hallway and waves his arms around, whooping and exclaiming as if to a grand crowd PASCAL

Visitor! We have a visitor!

Mena stands beside Ruchika, touching her hair and smoothing it off her shoulders, chattering away.

MENA

I can't wait to spend some quality time darling!

Ruchika stares straight forward. 'What have I gotten myself into.'

INT. CAROSIN'S BEDROOM, CANTERBURY. - MORNING.

Geoffrey enters, timid. Carosin stares out of the window, ignoring him.

GEOFFREY

We have to go now Caro.

Carosin is cold.

I hope you're okay...

CAROSIN

Stop being a little faggot Geoff.

Geoffrey is hurt. Carosin is furious. He leaves in silence. Carosin's face sets hard, she doesn't move at all.

INT. CAROSIN'S BATHROOM, CANTERBURY. - DAWN.

Carosin stands in a cold blue light. Searing hot shower. Spirals of steam float from her body. She stares forward, unmoving. 
The distorted sounds of a commentator, snatches of phrases. 'Perfect score' 'One to watch' 'Listen to that crowd'

Steam spiralling around her forms a crown, eyes fogging up. The distorted voice in her imagination booming into a crescendo. She closes her eyes as the sound of the water rises into a white noise roar.

Carosin's mouth, her overlapping front teeth biting down on her lower lip. Tension.

She remembers back -

EXT. DAIRY, CANTERBURY. - MID-MORNING.

A drop of ice lolly drips down the stick. Carosin (17) licks it from the stick before it hits her white cotton gloves.

Geoffrey (10) and Carosin lean against a rusted yellow truck across the road from the dairy, each with an ice lolly. One of Geoffrey's eyes is a paler blue than the other.

GEOFFREY

You know what cunnilingus is?

Carosin looks at him in disgust, then looks forward.

GEOFFREY

Course not. You're a girl.

Carosin raises her eyebrows, eating her ice lolly.

GEOFFREY

People think I don't know stuff.

They make prolonged eye contact.

GEOFFREY

I know stuff.

Carosin tussles his hair, he pretends to be annoyed and tries to fix it. His dishevelled hair reveals a strikingly visible blue vein in Geoffrey's temple, around his damaged eye. Carosin gently corrects his hair to cover it.

She looks away, and squints into the sun. The warm glow on her face, she closes her eyes. She softens. 
INT. CAROSIN'S BATHROOM, CANTERBURY. - DAWN.

Carosin, still biting her lip, with her eyes squeezed shut. Tension in her brow. A drop of blood rolls down her chin.

INT. LIFESTYLE BLOCK, CANTERBURY. - DAWN.

Through a small high up window, Ruchika watches Aunty Mena and Uncle Pascal drive away.

Ruchika, sat on the end of her perfectly made bed, looks at a small, fading picture of Pascal and Mena on their wedding day. She pans up to a gigantic, highly air-brushed and saturated image of them both hugging while jointly holding a large fish. It appears to have been taken in a professional studio.

Their eyes scream, the smiles are frozen. The fishes gaping, dead mouth and hollow eye.

Silence but for a running tap. The tap ceases.

INT. RUCHIKA'S ENSUITE BATHROOM, CANTERBURY. - EARLY MORNING. The clatter of a ring being placed on the side of a basin. A drip of deep red falls from Ruchika's hairline, dribbling down her forehead.

Her bare hand holding a pair of henna-stained scissors on the side of the basin.

Ruchika stares at her reflection, taking stock of her own daring action.

Her previously long, black hair now sits above her shoulders, roughly cut into a blunt bob with a block fringe.

She gently wipes the falling drop of red liquid.

She pulls a bare, henna covered hand through part of her deep rouge, henna soaked hair.

She stares at herself, a stranger. She lets out a surprised chuckle and then, outraged at her own daring, her laughter builds, almost hysterically. She has power. 
EXT. CANTERBURY FIELDS. - EARLY MORNING.

Ruchika, hair now rinsed and dried, a dark crimson and unevenly cut, walks through the fields around Mena and Pascal's property. She wears borrowed gum boots and a traditional, but bejewelled sky blue Malaysian tunic, stolen from the very back of Aunty Mena's wardrobe.

She looks around, even spinning, to take in the whole scene. It is a beautiful spring morning. Still.

EXT. CANTERBURY FIELDS. - MIDDAY.

Ruchika has been walking for a while and continues serenely. She reaches a fence. She comprehends the fence.

A scuffling noise several meters away. Ruchika investigates.

A wild rabbit is wedged underneath a gap in the fence that is not big enough. The animal struggles and kicks in distress.

Ruchika attempts to lift the fence, but finds it solid. She takes off her cotton gloves and pushes it upwards hard.

Strain in her upper arms. The fence posts rising out of the earth, tension in her jaw, her eyes squeezed closed.

She releases the fence, it slams down into the post holes.

She opens one eye cautiously. 'Please don't let me see a squashed rabbit'.

The rabbit is nowhere to be seen.

Relieved, invigorated, Ruchika hops the fence. She lands hard, lower than she should have.

INT. RABBIT HOLE. - MIDDAY.

The struggle as Ruchika wiggles her foot, dislodging earth. Ruchika wrenches her foot from the hole.

EXT. CANTERBURY FIELDS. - MIDDAY.

Ruchika gazes down at the muddy brown hole in the earth, and her thoroughly dirty boot.

CUT TO:

Later, and much further into the field, Ruchika gazes. 
The dark opening of a horse barn. A large house behind it in the distance. The black hole of the doorway.

INT. HORSE BARN, CANTERBURY - - MIDDAY .

Ruchika's curious head pops through the door. She knocks on the side of the frame ineffectually.

Silence and sepia ornaments. An empty horse stall. Hay.

Ruchika proceeds, cautiously, running her bound fingerprints over the rusted sink, the rough wood of the stall door, the dented tin of a trough, flecked with blue. Textures.

She looks to the empty stall.

INT. CAROSIN'S KITCHEN, CANTERBURY. - MIDDAY.

Carosin, dressed in her full riding gear and helmet, gently bangs her head against the wall of her kitchen over and over again.

Carosin gently bangs her head against the work surface, her body at a perfect right angle.

Kneeling by the doorway, Carosin gently bangs her head against the floor.

EXT. CANTERBURY FIELDS. - EARLY AFTERNOON.

Carosin's house in the background. Carosin's panting breath. Her pounding feet over grass. Her focused eye line.

INT. HORSE BARN, CANTERBURY - EARLY AFTERNOON.

Carosin stops in the doorway of the barn, hand on the frame. She looks to the empty barn.

She bends double, turning and vomiting into a drain grate over a ditch just outside the door.

Ruchika's startled head pops over the door of the stall. She puzzles over how to proceed. To speak? To hide?

Carosin spits to clear her mouth, wipes her face with her sleeve, turns back to the barn. Empty stall.

Ruchika's head pops up again, an apologetic smile on her face. 
Carosin jumps, yelling out in surprise. Ruchika yells too, falsely, realizes quickly that she shouldn't be, and stops.

Carosin stops yelling too. She wipes her mouth again. Ruchika tucks her hair behind her ear.

Ruchika glances around, unsure. Carosin stares at her, and laughs out of utter shock, quietly at first and then louder.

Ruchika softly chuckles too, smiling.

INT. CAROSIN'S KITCHEN, CANTERBURY. - EARLY AFTERNOON.

Carosin busies herself in the kitchen. Ruchika stands smack bang in the middle of the space, awkwardly gazing around herself. Curious.

$$
\text { CAROSIN }
$$

Surprised.

Carosin turns towards Ruchika.

Not scared.

$$
\text { CAROSIN }
$$

Ruchika smiles warmly at her. A moment of too-long eye contact. Carosin gestures wine. 'You want a glass?' Ruchika is taken aback.

$$
\text { RUCHIKA }
$$

Water, please.

Carosin pours herself a generous glass of wine.

\section{CAROSIN}

When the mice are away...

She registers Ruchika's shock and scoffs a little.

Their hands cross over as the glass of water is passed.

Ruchika registers Carosin's gloves. Carosin registers Ruchika's bound fingertips.

$$
\text { An accident? }
$$

CAROSIN

Ruchika nods.

CUT TO:

Later. Carosin is tipsy. 
CAROSIN

Oh well, fuck 'em ay.

Ruchika winces at the word. Carosin, earnest -

CAROSIN

Sorry

Realising -

CAROSIN

Hey... what's you name?

Laughter.

RUCHIKA

Ruchika Aasia Mahatir.

CAROSIN

Pleasure to meet you Ruchika Aasia

Mahatir, I am Carosin Hope Thomas.

Ruchika smiles with the knowledge that their middle names carry the same meaning.

CAROSIN

What're you doing here?

RUCHIKA

Woah racist!

CAROSIN

I mean in the middle of nowhere!

RUCHIKA

Just being .

Carosin exhales... That's a bit poetic for her. She drinks deeply from her wine glass.

INT. HORSE OF THE YEAR BEVERAGE TENT, CANTERBURY. - NIGHT.

Sandra tips back her glass of white wine, drinking deeply until the glass is empty.

She widens her eyes and blinks a lot, laughing as she swallows. Trevor, a representative from FreshHay Corp., raises his glass to her. He leans in to speak into her ear above the din, his hand on her lower back. Breath on neck. She giggles.

Across the tent, Rodney stares.

He drains his whiskey glass, numb. 
His phone rings, he answers, a little slurred.

Rodney Thomas.

RODNEY

Look this really isn't- [the time] •

The house? Now hold on you never

mentioned- [the house]

Isn't it enough that we're selling

the bloody horse?

That's very generous of you.

No I'll tell them.

Goodbye.

He returns to watching his wife. He gestures the barkeep for another whiskey, receives it, and walks out into the night.

EXT. HORSE OF THE YEAR BEVERAGE TENT, CANTERBURY. - NIGHT.

Rodney, a lone silhouette, walks away from the noise and clatter of the beverage tent, glowing golden behind him.

Shame.

The sound of a long dial tone.

INT. PRIYA AND AISAR'S APARTMENT, KL. - DAWN.

Priya stares out of the window at the sunrise, over the cityscape. Her phone is pressed to her cheek.

The long tone ends.

She hangs up and calls again, worry written on her face.

INT. LIFESTYLE BLOCK, CANTERBURY. - NIGHT.

Ruchika's mobile phone rings on a granite bench.

The sounds of laughing off-screen.

INT. CAROSIN'S LIVING ROOM, CANTERBURY. - NIGHT.

RUCHIKA

I've seen it on TV, but no, not in

real life.

CAROSIN

oh my god say it.

Ruchika looks stern. 


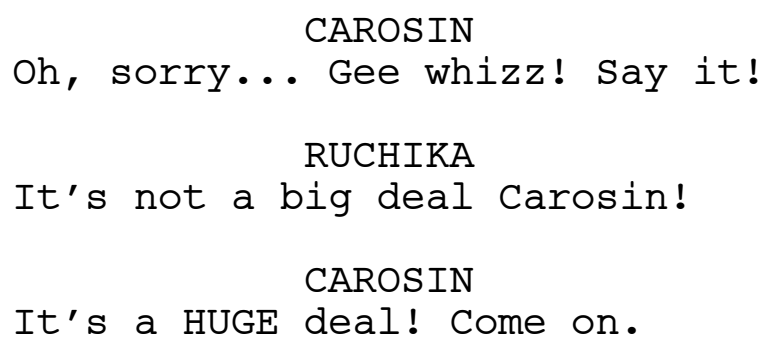

Ruchika shakes her head playfully . Carosin calms down.

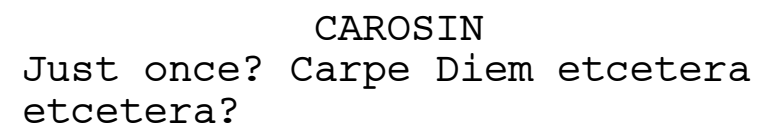

Ruchika stands, takes a deep breath, strikes a pose.

Ready?

RUCHIKA

Carosin nods eagerly.

Fuck.

RUCHIKA

Carosin does a huge victory dance around the room. Ruchika hides her face in her hands, laughing.

Carosin stops and grins, Ruchika's face is still hidden.

Carosin tilts her head, noticing a small swirl in the hair at the base of Ruchika's hairline.

Ruchika peeks through her fingers, catches Carosin's expression. They hold each other's eye contact for a moment.

INT. CAROSIN'S DOORWAY, CANTERBURY. - NIGHT.

Ruchika passes through the front door. Carosin watches her leave. She bites her lip, closes the door, leans her head back against it.

\section{Fuck.}

CAROSIN

EXT. CAROSIN'S DOORWAY, CANTERBURY. - NIGHT. Ruchika gazes at the stars. She mouths, 'What?'

INT. CAROSIN'S KITCHEN, CANTERBURY - DAWN. 
Carosin drinks a smoothie and runs her hand through her hair. She pauses at the base of her hair, where it meets her neck.

She feels the soft baby hair there. She bites her lip.

She keeps one hand on her neck and raises the other in front of her, as if searching another person's face. She explores

them. She caresses the invisible face and chin. She freezes.

INT. HORSE BARN, CANTERBURY - - VERY EARLY MORNING.

Carosin jogs toward the barn in her riding gear, helmet in hand. Ruchika is sitting just outside.

RUCHIKA

I wasn't sure of a polite way to get in touch.

Carosin smiles. A long moment of eye contact. Gestures playfully for Ruchika to 'Come hang out man don't be such a dork!'

Ruchika stands and they walk out into the field. She spins a small wild flower in between her forefinger and thumb.

INT. CORRIDOR OUTSIDE RUCHIKA'S APARTMENT. - EVENING.

A large bouquet of flowers. Zikri carries them to Ruchika's door. He knocks. A stern eye through the peep-hole.

Aabidah opens, smiling warmly. Secret flame.

He speaks, her face drops, she shakes her head.

The door closes in his face.

Zikri walks, only slightly deterred, to Doreen's door. He is nervous, Doreen is not an acceptable association.

He hesitates. He knocks. Eye in a peep-hole. Open door.

Zikri is surprised, and uncomfortable. Doreen luxuriates in his discomfort.

DOREEN

What can I do for you sir?

ZIKRI

Is Ruchika here? ... Please?

Doreen bites her fist. 
DOREEN

Oh buddy, that's such a burn, she didn't tell you?

Zikri looks like a lost puppy.

DOREEN

She's fully in New Zealand, for

like, an indefinite while...

Zikri is stunned.

New Zealand?

ZIKRI

DOREEN

Fully just so far away, in a big

and literal way.

ZIKRI

She didn't tell Aabidah-

Doreen shrugs, smug.

ZIKRI

I must've done something to upset her...

DOREEN

I think it was more the death

threats.

Zikri's face exclaims.

Doreen nods, sighs. She's bored.

DOREEN

Well I'd better be, ya know...

Zikri nods, distracted.

He blinks, startled, offers her the bouquet.

DOREEN

I'm good sweetie. I'm good.

She closes the door on him agonizingly slowly, looking around her apartment pointedly as she does.

Zikri stands in the hallway. He throws down the bouquet. He looks down at the flowers. He hates the flowers.

A moment. He picks them back up. He walks, placing them tenderly outside Aabidah and Ruchika's door. 
He jogs a few steps, looks back to check they remain, and then leaves.

EXT. CANTERBURY FIELDS. - MID-MORNING.

Ruchika is in the driving seat of a $4 \times 4$, stationary. Carosin stares at her.

INT. 4 X 4 . - MID-MORNING.

$$
\begin{gathered}
\text { RUCHIKA } \\
\text { It's just... not... } \\
\text { CAROSIN } \\
\text { You don't have to do it. }
\end{gathered}
$$

Ruchika unbuckles her seat belt and opens her door. They share a glance.

Door slam. Seatbelt click. Engine revving shooting two meters forward. Brakes slam.

Carosin is holding in a laugh. Ruchika looks angry.

Ruchika begins again, smoother, gentler. The engine ticks steadier as Ruchika drives in an infinity symbol around the field.

Over and over and over. Ruchika's expression shifts from determination to childish glee. Bandages catch with the friction of her grasp on the steering wheel.

Carosin gazes over at her, proud and impressed. She reaches across and touches the small swirl of Ruchika's hair with her thumb.

Ruchika looks surprised. The hand withdraws, a nervous smile. RUCHIKA

Your teeth are crossed over.

A hand goes to Carosin's mouth. Self-conscious, apologetic even.

\section{RUCHIKA}

$$
\text { It's lucky! In China... }
$$

Ruchika smiles a bright wide smile, slows the car to a clunky stop. 
The centre of infinity. Ruchika looks at the track she has engraved in the earth.

RUCHIKA

Right where we started.

How do you know?

CAROSIN

RUCHIKA

The sun is...

She cranes to look up at it's position.

RUCHIKA

And that line of trees.

She points to them, the bandage of her forefinger

unravelling.

Ruchika goes to tuck it in but Carosin gently, enquiring, unwinds it, undressing the secret.

As she unwinds it, they hold eye contact. Neither breathe. When Carosin reaches her skin, Ruchika softly massages the tip of her finger so it leaks henna, and presses it into Carosin's wrist in the space between her glove and sleeve.

Carosin is in wide-eyed disbelief.

She silently, unblinkingly, and holding Ruchika's gaze, removes her glove and unbinds her finger tip.

A ripple physically passes between and through them. Pause.

Ruchika presents her own forearm keenly. Carosin shakes her head and pulls her hand back slightly.

CAROSIN

It hurts people.

Ruchika takes her hand softly and holds it above her arm. RUCHIKA

Does it hurt you?

Carosin hesitates, then shakes her head. Young.

RUCHIKA

I'm like you.

Carosin smiles and guided gently by Ruchika, presses her finger, very lightly, to Ruchika's arm. 
Carosin admires her print, smiles. Ruchika smiles. Carosin watches the mark she's left, a glimmer of worry.

The pair sit in silence and stare out at the land.

CUT TO:

Later, the sun shifted in the sky, Ruchika rebinds her fingertip and starts the car up again, clunkily. Carosin looks down to her still naked fingertip. She anxiously rebinds her fingertip, and pulls a loose thread from it's fraying edge.

She gently drops the thread out of her open window.

The car passes, the thread floats slowly through the air, golden light behind.

INT. ARTIST STUDIO, KUALA LUMPUR. - NIGHT.

A thread falls through the air. The end of it is caught between Doreen's fingers.

Doreen sits with one of Ruchika's beautiful, but slashed canvases across her lap.

She threads the needle and begins repairing the canvas with tiny cross stitching to hold the slashed halves together.

Pensive, she lovingly smooths the fabric of the canvas in a large circle.

INT. HORSE OF THE YEAR BARN, CANTERBURY. - MIDDAY.

Geoffrey grooms Betty in grand sweeping movements. A passing equestrian star calmly slows and guides Geoffrey's hand in proper technique. He nods his thanks.

Leaning in close to Betty's ear, he softly speaks -

GEOFFREY

What does she tell you?

What do you know?

Betty whinnies and moves her head. In a moment of unexpected tenderness, Geoffrey kisses her cheek. He ceases grooming.

\section{GEOFFREY}

It's a shame she'd never let me ride you ay Betty, we could've been bosom friends. 
He stares at the horse. Betty blinks.

\title{
Bosom.
}

\author{
GEOFFREY
}

He grins and starts grooming her again.

INT. CAROSIN'S KITCHEN, CANTERBURY. - MIDDAY.

Ruchika and Carosin sit on either side of the kitchen table, piles of paper in front of them. They nod at the same time, unbind their hands. Small piles of bandage all stained navy and crimson. The women each press a fingerprint into the paper once.

Ruchika lifts her head. They stare. They smile relief. They start to make random prints and smudges all over the papers, exhilarated.

EXT. CAROSIN'S GARDEN PATIO, CANTERBURY. - AFTERNOON.

Ruchika sits under the erected umbrella at the table, doodling a flipbook drawing on the corner of a novel. Carosin lies on the patio, staring up into the sunshine, tanning with her shorts tucked up and her T-shirt pulled high to tan her midriff.

Ruchika flicks through the image she has almost finished constructing; a hand-drawn flipbook image of hands leaking from the fingertips and the drops falling, hitting liquid below and reverberating in outward circles, before forming little fish like forms that swim around and leap cheerfully.

She continues to sketch the next image as they joke, modelling a variety of accents and tones -

CAROSIN (AUSTRALIAN ACCENT)

Whaddaya got a skin infection or something mate?

Are you OCD or...?

\section{RUCHIKA (AMERICAN ACCENT)}

CAROSIN (FRENCH ACCENT)

Is it safe to shake your hand or...?

RUCHIKA (COCKNEY ACCENT)

Did you plunge your hands into boiling soup? 
CAROSIN (NASAL VOICE)

Don't spoil breakfast!

Or pet the cat!

RUCHIKA (MUCH LIKE PRIYA'S VOICE)

No high fives at school!

CAROSIN (GRUFF KIWI BLOKE ACCENT)

RUCHIKA

I can't touch anyone!

The laughter fades. Silence falls. Beat. Carosin shifts to look at Ruchika in lieu of the sunshine, moving up onto her elbows.

How old were you?

CAROSIN

RUCHIKA

Five. You?

CAROSIN

Seven.

... Rough...

A moment of shared reflection.

INT. CAROSIN'S KITCHEN, CANTERBURY. - MIDDAY.

Carosin prepares lunch while Ruchika prays in the next room. She watches her, bowing and chanting. She smiles softly.

Pensive. She wants. She wipes her hands on a tea towel and walks. She sits beside Ruchika, silently closing her eyes and meditating as Ruchika prays.

INT. CAROSIN'S KITCHEN, CANTERBURY. - AFTERNOON.

Sheets of paper cover the table. They are littered with fingerprints and smudges, all with pen annotations around them transforming them into different creatures, objects, places, landmarks, foodstuffs; an amazing variety of drawings.

EXT. CANTERBURY FIELDS. - AFTERNOON.

Carosin and Ruchika walk far apart, exploring, skipping, dancing in the sunshine. They are young. 
CAROSIN

What do you say, when you're praying?

RUCHIKA

Hmm, it's like a script mostly. Sometimes I ask for different things.

Have you ever prayed?

Carosin scoffs.

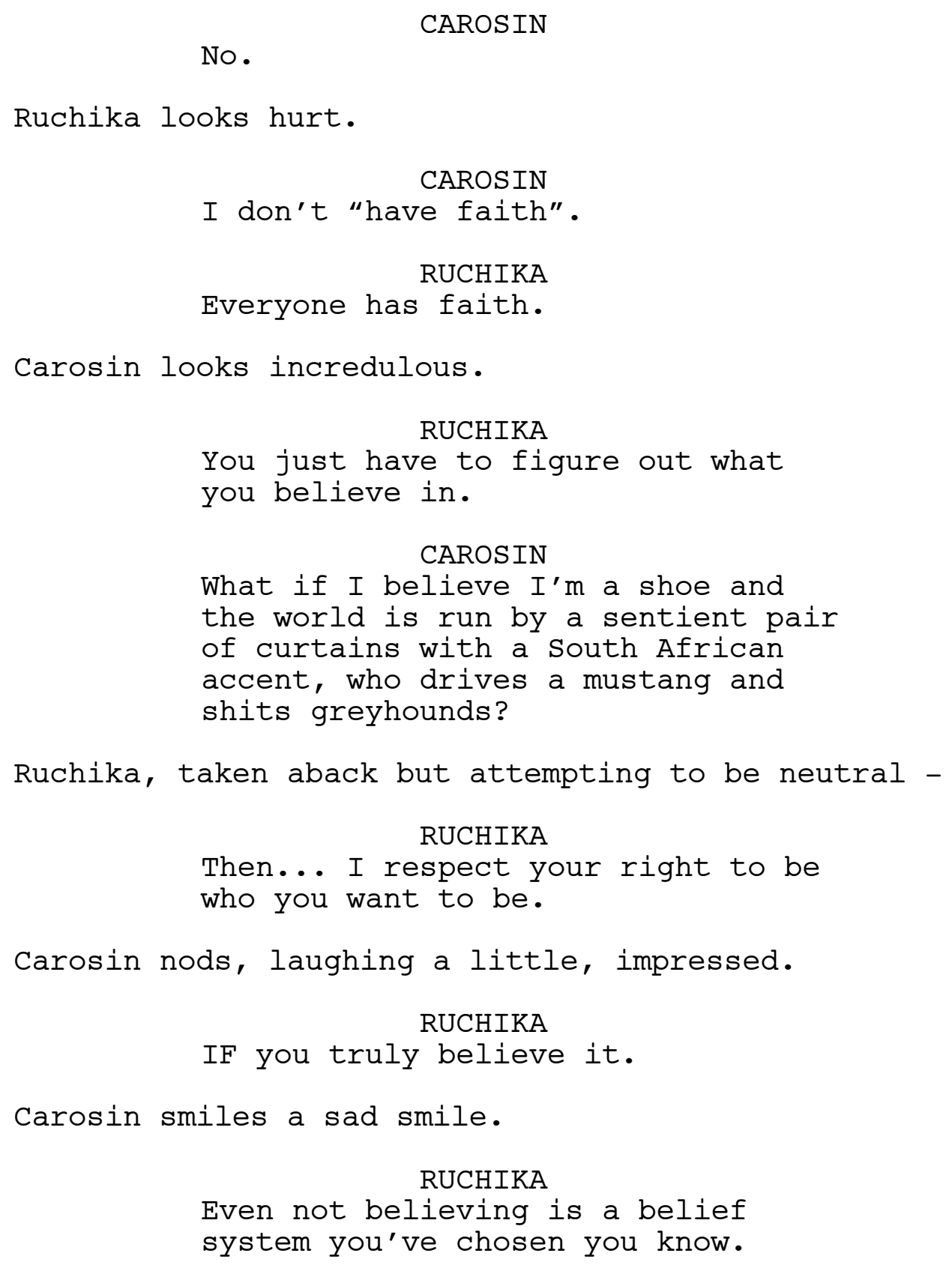

Ruchika, taken aback but attempting to be neutral -

RUCHIKA

Then... I respect your right to be who you want to be.

Carosin nods, laughing a little, impressed.

RUCHIKA

IF you truly believe it.

Carosin smiles a sad smile.

RUCHIKA

Even not believing is a belief system you've chosen you know. 
Carosin looks away, clears her throat.

EXT. BACK PORCH, LIFESTYLE BLOCK, CANTERBURY. - EVENING.

Ruchika draws intricate and beautiful henna up Carosin's hand right up to her elbow. The silhouette of a galloping horse is worked into the pattern, it runs towards the tips of Carosin's fingers.

Ruchika finishes, pauses and looks with concern at Carosin. Carosin turns to her. Her lips are parted. Her crossed teeth. Carosin glances to the swirl in Ruchika's hair, then to her eyes. Prolonged eye contact.

$$
\begin{aligned}
& \text { CAROSIN } \\
& \text { She'll come back. }
\end{aligned}
$$

INT. LOUNGE, LIFESTYLE BLOCK, CANTERBURY. - NIGHT.

Ruchika sits, peering over the back of the sofa. Carosin sings along, in the kitchen, to a Gwendolyn Prair song. She is dancing, bending double with emotion, finishing preparing a banana split with marshmallows, crushed nuts, chocolate sauce.

Ruchika claps in child-like delight. Carosin jumps over the back of the sofa with two bowls. They smile. They begin to eat.

Ruchika gets brain freeze. She communicates this through gestures and a crazed facial expression.

Carosin sympathises, touches her gloved hand to Ruchika's knee and goes to get a glass of water for her.

Ruchika pauses, no longer fussing, and stares at the place on her leg that Carosin touched. Warmth.

Carosin, at the sink, fills a glass with water and drums the fingers of her hand against the glass. Warmth.

INT. CAROSIN'S BEDROOM, CANTERBURY. - MID-MORNING.

The next day, Ruchika sits on Carosin's bed, looking through family photos, relaxed and curious. 


\section{Amazing.}

\section{RUCHIKA}

She holds up a photo of Carosin (8) holding a baby Geoffrey and kissing his forehead. Carosin shrugs.

RUCHIKA

Family is... so much.

Carosin doesn't respond. Ruchika's warm expression flitters to curiosity, she glances about the room.

\section{RUCHIKA}

You don't have any recent photographs?

CAROSIN
I just take them in here now.

She taps her forehead. Ruchika puzzles.

\section{CAROSIN}

When I want to keep something I close my eyes really tight and I commit the image to memory.

Ruchika places the photographs in a neat pile and back into the box. Carosin takes a sneaky snap shot of her while she isn't looking, just for fun. Ruchika turns towards her again -

It really works?

$$
\text { RUCHIKA }
$$

\section{CAROSIN}

Oh yeah, I've got all the good

stuff. Birthdays, tournaments, Christmases, even a naked picture of Justin Bieber.

Ruchika smirks.

$$
\text { Oh really? RUCHIKA }
$$

Carosin shrugs, smiles. She collects the photos and moves them to one side, and bounces on the bed on her knees, flipping over and staring at Ruchika.

Ruchika leans over Carosin, threatening to dribble on her. Ruchika lets a drip dangle from her mouth for a long moment and as Carosin protests, shocked, Ruchika laughs, before sucking it back in and wiping her chin. She grins. Carosin looks faux-outraged. 
EXT. CANTERBURY FIELDS. - MIDDAY.

Carosin and Ruchika spin in the soft rain of an irrigation sprinkler, their mouths open to the moisture, arms spread wide. Their hands collide a few times as they spin. Ruchika chokes a little on her own backsliding tongue, sputters. Carosin laughs gleefully. Ruchika chuckles and calms, looking bemused. Carosin keeps laughing, so hard that she doubles over. Ruchika watches.

Ruchika's face under the falling water of the gigantic irrigation sprinkler, with her hair wet and love in her eyes. A wide smile as the water falls behind her. Carosin squeezes her eyes tight closed, grinning, the water bounding off her face.

Ruchika gestures around her as if apologizing to an invisible crowd of people. Glancing at Carosin, she pulls faces as if to say 'I definitely don't know her' to the invisible bystanders.

Then she realizes what Carosin is doing and freezes.

Carosin opens her eyes, still laughing. She straightens up and calms rapidly as Ruchika steps the few metres between them. Carosin's face is level with Ruchika's and matches her sudden seriousness.

They hold each other's eyes. Me too.

RUCHIKA

Carosin's expression sinks into earnestness. She glances rapidly from one of Ruchika's eyes to another.

She leans, then she pauses, unsure.

She kisses Ruchika with a depth that tries to communicate just how much this means. There is urgency.

Ruchika kisses back for a long moment.

And then she pulls away.

Flustered and sputtering under the water -

RUCHIKA

$$
\text { I'm not... }
$$

The words in Carosin's mind echo. They stand in the falling water, not looking at each other. Carosin is humiliated. 
CAROSIN

You're not bad to- if you want...

RUCHIKA

My faith is not cruel to me.

Their eyes meet. They hold.

I love you.

CAROSIN

Ruchika looks away again.

\section{Fuck.}

\section{CAROSIN}

She tries not to let on how upset she is, biting her lip. Ruchika looks down at her bare limbs. RUCHIKA

I shouldn't be like this.

She runs to get her shawl from outside the reach of the irrigation rig.

Carosin watches her get further and further away.

Ruchika, now with a dry garment, stares back at Carosin. She doesn't want to re-enter the water. She hesitates, frozen.

Carosin shakes her head, and walks in the other direction.

Ruchika takes a step forward but is kept at bay by the water, falling steadily.

Carosin keeps walking, towards home.

INT. HORSE BARN, CANTERBURY. - EARLY AFTERNOON.

Carosin sits in Betty's empty stall, spinning hay between her bare fingers. She is still soaked from the irrigator.

She closes her eyes and pulls her knees into her chest, arms wrapped around herself.

INT. OPEN COAT WARDROBE. - MIDDAY.

Carosin (8) has her knees pulled up to her chest, her arms wrapped around. She is singing to herself quietly. 
CAROSIN

Riding in sunlight, Hiding in plain sight, Things will be alright, Baby just sit tight.

The sound of a gurgling cry of distress from a baby.

As she sings quietly, Geoffrey (1) with blue spit up on his bib, lies on the floor. He is clearly unwell in a terrifyingly calm, sputtering sense. The veins around one eye and temple are standing out a vibrant blue. One of his eyes is much lighter than the other.

Carosin buries her head into her arms, squeezing her fists tighter, they leak blue liquid through the spaces between her fingers. Tension. Rocking gently backwards and forwards, she begins to hum the tune again.

EXT. FIELD, CANTERBURY. - AFTERNOON .

The tune carries on, higher pitched.

Ruchika sits, soaking wet too, on the grass. Cross-legged, she contemplates the rabbit hole, depth of brown.

A place to hide.

She gently touches her unbound finger to her lips.

INT. TOILET FACILITIES IN BUILDING BESIDE MOSQUE, KL.

A small forefinger in a child's mouth.

A small pair of white cotton gloves balanced on a hose holder.

Ruchika (8), tall for her age, removes her finger from her mouth to carefully lift her dress, and squats over the squatting toilet.

When she is finished, she writes on the back of the door in small, childish font.

The sound of women entering the bathroom, chattering, their clothes rustling, hurried. Ruchika freezes, rebinds finger and collects her gloves.

The door swings closed slowly.

We read, in red brown: I AM NOT NORMAL. 
A drop rolls down from the final letter where there is more henna. It falls very slowly.

EXT. FIELD, CANTERBURY. - AFTERNOON.

Softly, quietly, a tear rolls down Ruchika's cheek. With unbound hands, she wipes the tear with the back of her hand, and then buries her hand into the rabbit hole and brings it out, a clenched fist full of rich earth. She rubs it across her face.

She stands, desperate and turns to the sun. She calls out in Arabic, a common prayer for guidance and aid.

A war rages inside her. She channels it into her long, vulnerable, guttural call.

Carosin stands behind her some distance, frozen. She has never seen an outpouring like this, never witnessed emotion so raw and with such power.

The call goes on.

Ruchika slows, calls out a couple of short phrases, and then stops. She's exhausted. She hurts.

A moment of stillness for them both.

Carosin makes the decision. She marches towards Ruchika.

She stops a respectful distance away. She has to yell.

CAROSIN

You don't have to be anything.

Ruchika, surprised, turns to her. They stand in the heat.

Words catch in Ruchika's mouth, she feels sick with the pressure as they pulse in her throat. So many things.

She turns away; she can't be that person.

Carosin pleads softly, compassionately.

Just stop hiding.

CAROSIN

You don't have to be anything.

Ruchika pauses. Turns back. They stare into each other's eyes.

Ruchika makes her decision. She marches right up to Carosin, who looks frankly taken aback and a little apprehensive. 
Ruchika, reaching her, takes her head in both hands and kisses her, hard, urgently.

Carosin is so surprised she just stands for a few second, before her hands cautiously go to Ruchika's waist. They hover an inch above the surface of her skin, respectful.

After several long, passionate kisses, Ruchika pulls back. Her face is a mess of dirt and sweat. They are vibrant in the dazzling sunlight.

Ruchika runs her hands down Carosin's bare arms and presses her hands into her waist. They kiss again, gentler, more indulgent, still confused and vulnerable but sure in some way now.

We look upwards towards them, so that they are heightened, existing in the blue of the sky, unhampered by physical situation.

The sun moves across the sky as they kiss, until it is setting behind them. A cold blue light. Ruchika pulls away. She smiles a somewhat sad smile.

Carosin watches as Ruchika, in the distance, walks home.

INT. LIFESTYLE BLOCK, CANTERBURY. - AFTERNOON.

Ruchika sits on the end of her bed, her skirt pulled up and her wrists tucked between her bare thighs. She sighs.

She looks at herself in the mirror at the end of the bed. She whispers -

\section{RUCHIKA (BAHASA MELAYU)}

I don't know you.

She releases her wrists and raises her bare hands to her hair, grabbing at it. She bows her head.

She notices that Carosin's fingerprint has imprinted on her thigh where her wrist made contact. She inspects the print.

INT. RUCHIKA'S ENSUITE BATHROOM, CANTERBURY. - EVENING.

Perched on the edge of the bath in a towel, Ruchika wraps a bandage around her thigh over and over, protecting the fingerprint and hiding it away. She secures the bandage and raises her head.

She closes her eyes and exhales. 
We see her entire body covered in dark navy fingerprints and smudges.

A calm tear rolls down her cheek.

A roar begins in her head. She gasps, and her body heaves with the weight of all she carries.

INT. CAR DRIVING THROUGH RURAL CANTERBURY. - EVENING.

The hollow roar of the car's interior.

Geoffrey, Rodney and Sandra are piled into their car, all of them staring ahead. They are all numb. The horse trailer follows behind.

The car veers slightly into the judder-lines. The driver corrects the trajectory. No-one blinks.

INT. AEROPLANE CABIN. - DAWN.

The roar of the cabin's interior.

Ruchika rubs at the blue smudge still on her arm. Everyone else is asleep around her, they are mid-way through their flight.

She looks out the window, white clouds and blue sky just lit by the rising sun. She winces. She has a head ache. The clouds reflect in her irises.

She places an aeroplane blanket over her head. From inside the blanket, with her eyes open, the loose weave letting in light looks like a starry night.

EXT. CANTERBURY FIELDS. - NIGHT.

The starry sky of a rural New Zealand town.

Carosin lies on her back on the grass, a bare fingertip tracing her mouth over and over. Her lips are painted blue.

INT. HORSE BARN, CANTEBURY. - DAWN .

Carosin strides, nervous and excited, up to the barn, not in her riding gear.

There is a note pinned to the door. Carosin reads it, optimistic. Her face slowly shifts to sadness, confusion. 
She scrunches up the note. Fuck.

EXT. CANTERBURY FIELDS. - DAWN .

She power walks towards Mena and Pascal's home. She jumps a fence without blinking. A wild rabbit runs across her path, she pays it no mind, 'Damn pests'.

EXT. LIFESTYLE BLOCK, CANTERBURY. - DAWN .

Carosin stands in the entrance way, jiggling a leg. No one is answering the door. No cars are in the drive.

Carosin walks out into the driveway and holds the note up to Ruchika's window. With a lighter from her pocket, sets it on fire. She pulls the finger at the empty glass.

In the early light, as the flames swallow it up, we see that the note simply reads -

$$
\text { I CAN'T. }
$$

INT. CAROSIN'S KITCHEN, CANTERBURY. - MORNING.

The whole family have just returned home and are in the Kitchen. Geoffrey has clearly been crying and stands waiting for the kettle to boil. Rodney places his damp shoes below a bar heater and turns the dial to 'VERY HEATED'. Sandra covertly snaps an Emergency Contraceptive Pill into her hand from her handbag and throws it back with a sip of water.

Carosin enters. Click. The kettle boils.

All heads turn to her. Everyone moves to sit around the table. Rodney gestures for her to sit down too.

CAROSIN

okay, hi, good to see you too.

RODNEY

Something happened, while we were away.

CAROSIN

What'd you shoot her?

Rodney sighs.

SANDRA

We're fucked Carosin, and it's all

your fathers fault. 
RODNEY

We're all in a bad place and, well, unfortunately it's come to the point where we've had to make-

SANDRA

We've sold Betty. She's gone

tomorrow.

Rodney looks at her, aghast.

SANDRA

Like a band aid Rodney.

Carosin suddenly looks like a small girl, bewildered, searching. Sandra, avoiding her gaze, gets up from the table and goes to pour herself a drink. Geoffrey looks lost. Rodney begs forgiveness with his eyes.

Scrape of chair legs. Carosin stands.

Time?

CAROSIN

RODNEY

In the morning, early. Honey I'm sor - [ry]

But Carosin can't hear, she's marching out the front door.

EXT. CAROSIN'S HOME, CANTERBURY. - MORNING.

Carosin unlocks the horse trailer roughly and leads Betty out.

They walk to the horse barn.

EXT. HORSE BARN, CANTERBURY. - MORNING.

Betty is fitted with a saddle and reins. Carosin mounts her. They trot off into the distance.

EXT. CAROSIN'S HOME, CANTERBURY. - MORNING.

Rodney and Sandra stand in the doorway and watch her in the distance. Sandra scoffs and goes inside.

INT. CAROSIN'S KITCHEN, CANTERBURY. - MORNING. 
Sandra walks through. Geoffrey looks up, lost. She glances to him, keeps walking. He looks after her, and then out of the window to his sister's disappearing form.

EXT. CANTERBURY FIELDS. - DAYTIME.

Carosin rides.

EXT. CANTERBURY FIELDS. - DAYTIME.

Carosin pats Betty's neck as she leans and drinks from a stream. Carosin sits down beside the drinking horse, removes her gloves, and cups the water to drink.

EXT. CANTERBURY FIELDS. - EVENING •

Carosin stands atop Betty with her arms raised in her standard victory pose, silhouetted by the setting sun. Silence.

EXT. HORSE BARN, CANTERBURY. - EVENING.

The pair return to the barn, exhausted.

INT. HORSE BARN, CANTERBURY. - NIGHT.

Barely visible in the rural dark, Carosin removes Betty's reins and saddle. She bows her head to Betty's. They breathe together. Carosin whispers -

\section{CAROSIN}

I love you.

She wipes her face, rubbing at her eyes, she sniffs. She squeezes her eyes tight shut for a moment. A tear escapes. She opens her eyes. She leaves the barn.

INT. CAROSIN'S BEDROOM, CANTERBURY. - NIGHT.

Carosin takes a book from her shelf. She opens the cover to reveal a false middle, full of certificates and envelopes.

She opens one, inside is $\$ 500$, she opens another, inside is $\$ 80$ and a scrubby handwritten note reading 'Geoffrey owes Carosin $\$ 20$ for snacks. Don't be mad. You ate some of the snacks too. Sorry. Love you.' She reacts. 
She takes several other envelopes too and puts them in the front pocket of a big backpack. She opens her clothing drawers .

INT. LIZZY'S CAR, DRIVING THROUGH CANTERBURY. - 3 AM.

They drive in silence. Lizzy glances at Carosin. Carosin stares straight forward, unflinching. She looks wrecked.

INT. RUCHIKA'S APARTMENT, KUALA LUMPUR. - MIDDAY.

Ruchika stands in the doorway to her apartment as Aabidah walks away. Her suitcase in hand, she looks awful; clammy, exhausted, pale.

Aabidah's door clicks closed. Ruchika collapses.

Aabidah's feet rush back. She shakes Ruchika's unconscious form gently. As she does, Ruchika's skirt falls slightly to the side, revealing blue veins standing out through her skin around her thigh. The veins around her eyes, and the blue smudge on her forearm, are also slightly more prominent and visible.

INT. HOSPITAL, KUALA LUMPUR. - EVENING.

Ruchika's eyes open with a start, somehow paler.

From her perspective, we see the world in blue tones, with rough focus. She has to work to see clearly, and pain behind her eyes.

Aabidah, beside the bed, holds Ruchika's hands. She is softened.

They make eye contact. Ruchika looks terrified, searches Aabidah's face, her breathing erratic.

INT. AEROPLANE CABIN. - NIGHT.

Carosin wakes with a start, a searing pain her eyes. White noise. She snaps her eyes closed and pushes down on them with her bound fingers. She exhales deeply.

INT. CAROSIN'S BEDROOM, CANTERBURY. - MORNING.

Geoffrey knocks tentatively, and enters the room carrying a tray of boiled eggs and toasty soldiers. He sees her empty bed covered in clothes and her open, empty drawers. 
Muuuuuummmmm?

GEOFFREY

INT. KUALA LUMPUR CUSTOMS. - MIDDAY.

Carosin sticks out like a sore thumb in a disorderly and lengthy queue full of modestly dressed women in burqas. She pulls her sleeves down and pulls down her top to cover an inch of exposed stomach. Seeing her chest more exposed, she pulls it up again. She is sweating and uncomfortable.

She stares at a guard with a large gun.

A large man kicks her hard in the ankle as he barges past her. She grabs at it in pain.

EXT. KUALA LUMPUR AIRPORT. - MIDDAY.

Carosin hails a taxi, limping a little.

INT. HOSTEL RECEPTION, KUALA LUMPUR. - AFTERNOON.

Carosin, flustered, speaks to a bored and impatient staff member.

\author{
CAROSIN \\ I just, I don't know how long I'll \\ be here for, I'm sorry.
}

INT. HOSTEL ROOM, KUALA LUMPUR. - EVENING.

Carosin unpacks her bag and begins to search through a phone book, she highlights an address.

INT. HOSTEL RECEPTION, KUALA LUMPUR. - MORNING.

The same hostel worker highlights a route on the map, circling several locations across the city - Art galleries.

INT. BUS, DRIVING THROUGH CENTRAL KUALA LUMPUR. - MORNING.

Carosin sits looking out the window, referencing a map with a route drawn on it. She looks for street names. There are none. She is panicking. At the next stop she searches around her keenly. A stranger (male, 30s) sits down in the seat beside her. After a moment - 


\author{
STRANGER \\ Where are you going? You need \\ directions?
}

Carosin stares out the window, unblinking, she moves as far away from him as she can. He spreads his legs so that his thigh is touching hers. She presses the stop button and gets off, pushing past him somewhat on her way out.

EXT. BUS STOP, CENTRAL KUALA LUMPUR. - MORNING.

Carosin exhales and shakes out the tension in her arms and clasped hands. She looks at the map again. She checks google maps on her phone. She glances to a sign nearby.

INT. ART GALLERY, KUALA LUMPUR. - MIDDAY.

Doreen monitors their small exhibition. It is shabby and small but it is charming, and Ruchika's work is good.

Doreen, a little bored, flips through a flipbook beside her, specifically made for her. She smiles as she flicks through, watching the hand drawn image of a hand gently sliding an engagement ring onto another person's wedding ring finger. They hold hands, and their arms swing to and fro, further away from and closer to the viewer in turn.

The sketches are on sketchbook paper, and are bound with ribbon.

Carosin gazes at the blood sweat and tears canvas, whispers -

Wow.

CAROSIN

Doreen looks up. Carosin is in awe, totally still.

Carosin goes to Doreen at her desk. She looks at postcards, scans a book, fanning the pages. The cool air hits her. She does it again with it far closer to her face, the welcome cool.

Alright there?

DOREEN

Carosin smiles, putting the book back.

CAROSIN

Do you know how I can contact the artist please? 
DOREEN

We don't give out that information, there has been past vandalism.

Oh.

CAROSIN

Carosin picks up some small printed postcards of Ruchika's work and pops them on the desk. Doreen rings them up. Carosin tilts her head, listening to the music playing softly in the background.

CAROSIN

Is this Gwendolyn Prair?

Doreen smiles and nods, hands her the postcards.

INT. RUCHIKA'S LIVING ROOM, KUALA LUMPUR. - MIDDAY .

Ruchika limps over to zikri with two cups of tea. She sits down beside him on her sofa, a meter apart, placing the tea on the table before them. Zikri is crestfallen. Lost.

\section{ZIKRI}

It's always been us, since scraped

knees and chalk painting...

I do love you.

RUCHIKA

Zikri is silent, hurt.

\section{RUCHIKA}

I have always tried to give you

joy.

She reaches for his hand. He looks to her, tears well. In a moment of intense affection, he kisses her cheek.

She pushes him away gently, a hand to his cheek. Her hands, bandaged at each fingertip, settle of each side of his face. Beat. She glances between his eyes rapidly. She moves forward, kissing him passionately.

They stand up, still kissing, and move towards her bedroom.

\section{FLIPBOOK PAGE SEQUENCE.}

In hand-drawn flipbook animation style, we see Carosin, reaching out to the viewer, here embodied in Ruchika. Carosin offers her hands and lifts Ruchika into view and onto Betty's back. 
They sit facing each other as they gallop through central Kuala Lumpur. They kiss as the sun rises.

A long moment of eye contact, her smile, her crooked teeth. Ruchika leans in to kiss her again, but an earthquake shakes them. And then a bigger earthquake, one that shakes them into falling from the horse. We see Carosin's panicked face as she falls fast, reaching out for Ruchika's help.

INT. RUCHIKA'S BEDROOM, KUALA LUMPUR. - AFTERNOON.

Ruchika wakes with a start. Zikri mumbles in his sleep.

Ruchika moves Zikri's arms from around her delicately. He is holding her tight and it is difficult. She really doesn't want to wake him. She dresses cautiously, in silence. She still has a bandage protecting Carosin's fingerprint on her thigh. She clocks it.

INT. RUCHIKA'S LIVING ROOM, KUALA LUMPUR. - AFTERNOON.

She softly closes her bedroom door, and walks past Aabidah's room - it is empty. That's good. She takes the cold tea and pours it down the sink.

She closes the front door behind her.

INT. OFFICE, KUALA LUMPUR. - AFTERNOON.

Ruchika sits in Jaiyana's office. We see them through glass, muffled speech. Jaiyana is angry.

JAIYANA

What do you mean colour blind? That makes no difference!

A moment of stillness, Ruchika's face is calm and patient. Ruchika resolutely walks from the office. Jaiyana calls out JAIYANA

I would've thought more of you than just a good wife Ms. Mahatir!

Ruchika keeps walking. She is hurt by the remark, but overwhelmingly relieved to be free of her work.

EXT. STREET VENDOR, KUALA LUMPUR. - EARLY EVENING.

Carosin gratefully accepts a large bowl of curry and rice. She inhales the smell greedily and nods her thanks. 
She takes a bite. The vendor looks incredulously after her. 'Holy shit that's spicy. Oh god.' She nods her thanks again, exhaling, and begins to walk with the food.

A bus passes.

INT. BUS, DRIVING THROUGH KUALA LUMPUR. - EARLY EVENING.

Ruchika sits, her hair still messy, visibly poking out from the edges of her hijab. She is numb and disconnected. She stares out of the window. Exhausted. Happy?

INT. HOSTEL ROOM, KUALA LUMPUR. - EVENING.

Carosin sits in the adjoining bathroom. She sits on the toilet with her hands on her stomach. She wretches, vomits into the shower in front of her, trying to move the curtain in time but barely making it. She wipes her mouth afterwards, pushes the curtain, now bearing brown vomit, to the side. She sits back. Groans.

INT. HOSTEL KITCHENETTE, KUALA LUMPUR. - EVENING.

Carosin stares downwards slightly, exhausted. She stares at the open cutlery draw, the one sharp knife. She takes it out and points it straight down into a wooden chopping board. She places her wrist beside the knife at a few inches distance. She spins the knife, driving the point into the wooden board. A hollowed out dot to match her cigarette scar.

She leaves it there. The knife. The board. Her wrist.

The delicate balance of the blade, sharp edge pointing towards her flesh, with just her index finger to hold it upright. She stares.

INT. ART STUDIO, KUALA LUMPUR. - NIGHT.

Ruchika stares down at a palette with multiple different paints on it. We see through her eyes, they are all very similar shades of blue. She breaths out.

Doreen is beside her, with a canvas of her own. She watches Ruchika.

DOREEN

Let's do this lady.

Ruchika nods, smiles. She dips a paint brush into a paint. 
When her brush is an inch from the canvas, she halts. Doreen watches intently. A breath. Ruchika starts to paint. Fast. She crafts a beautiful image of a woman's hands, she incorporates arabic text as well as wedding henna patterns.

Doreen is impressed. Relieved. Until Ruchika goes to get more paint, inadvertently calling on a different colour. She keeps painting, ruining it more with every stroke as the colours clash and combine to a grotesque green.

Doreen, panicked, watches... should she stop it? Ruchika is excited, gleeful. Doreen's face becomes more and more worried.

Manic, Ruchika steps away from the painting, gazing at it proudly. She looks to Doreen's apologetic gaze, and then back to the painting.

Ruchika begins to paint slashes across the image, distorting and disguising it. Doreen goes to stop her and Ruchika resists. She flips the paintbrush and stabs it through the middle of the image.

Woah lady •

$$
\text { DOREEN }
$$

RUCHIKA

FUCK •

Doreen is shocked. They pause for a moment. Ruchika shakes her head, frustrated.

DOREEN

Woah, I am trying to be supportive.

\section{RUCHIKA}

I don't need your support.

DOREEN

I think you do, now especially.

Ruchika looks questioningly at Doreen, a hardness in her.

DOREEN

I think you've got some things to admit to yourself and in our lives, in our... situation, that's a difficult thing.

\section{RUCHIKA}

I don't have anything to admit.

Ruchika...

DOREEN 
She gestures at the painting. Romantic. Feminine.

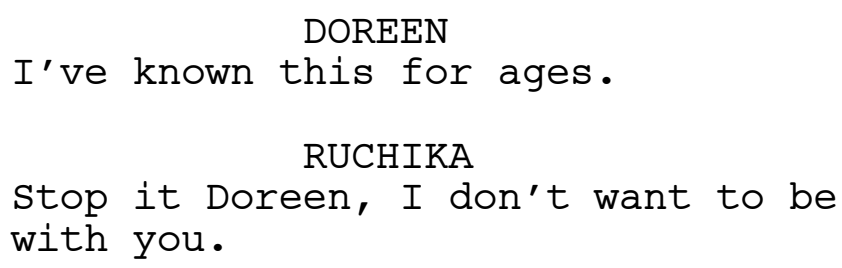

Doreen is appalled at the insinuation, and instantly cold and harsh.

Ruchika sees this, bristles. She takes the canvas off it's perch and snaps the edge over her knee, throwing it to the ground as she leaves. She mutters -

$$
\begin{gathered}
\text { RUCHIKA } \\
\text { You don't know anything. }
\end{gathered}
$$

Doreen watches Ruchika as she rip off her gloves, storming out of the studio.

INT. HOSTEL ROOM, KUALA LUMPUR. - NIGHT.

Carosin sits, looking miserable and still quite unwell, staring at her laptop.

Her mouse hovers over 'confirm payment' on a flight home for the day after tomorrow.

A long moment. She looks around, catches her reflection in a wall mirror. She looks gaunt and feeble, pathetic.

'I'm not okay'. She clicks to confirm payment.

She falls backwards in bed and a spasm of anger passes through her whole body. She lets out an exhausted sigh.

INT. RUCHIKA'S BATHROOM, KUALA LUMPUR. - NIGHT.

Ruchika lets out a bumped breath, trying desperately not to vomit, crouched over the toilet. She vomits. She slumps against the wall beside the toilet and wipes her mouth. A moment of utter self-pity.

We stay with her in this lowest moment, as we hear her, speaking weakly, on the phone to her Doctor (Female, 35) -

RUCHIKA (V.O.)

You said that I wouldn't get any sicker?! 
DOCTOR (V.O.)

I'm sorry Miss Mahatir we simply

don't have time to examine you

today. Can you rule out food

poisoning? Or morning sickness?

INT. RUCHIKA'S BEDROOM, KUALA LUMPUR. - NIGHT.

Ruchika lies in bed, sweaty, anxious, awake.

$$
\text { Morn- what? }
$$$$
\text { RUCHIKA (V.O.) }
$$

Dial tone. Ruchika stares at the ceiling.

INT. PHARMACY, KUALA LUMPUR. - EARLY MORNING.

Ruchika stands in the pregnancy care aisle, staring. The dial tone continues.

EXT. PHARMACY, KUALA LUMPUR - - EARLY MORNING.

Ruchika exits the pharmacy and powers away. We stay on the very concerned face of the Pharmacy assistant.

INT. RUCHIKA'S KITCHEN, KUALA LUMPUR. - MORNING.

Ruchika sits at the kitchen table staring at the test. The line at the end of the stick is blue.

Ruchika rereads the instructions. 'A bright blue indicates a positive result, a bright pink indicates a negative result.'

She stares down at the stick. Her eyes fill with frustrated tears.

INT. CORRIDOR OUTSIDE RUCHIKA'S APARTMENT. - MORNING.

She knocks at Doreen's door. She waits... For a long time.

INT. RUCHIKA'S APARTMENT, KUALA LUMPUR. - MIDDAY.

Ruchika sits at the kitchen table, face turned away, holding the pregnancy test in front of her, waiting for Aabidah to return home, silently crying.

The light shifts dramatically. It is hours later. 
Aabidah enters. Ruchika is frozen. Aabidah walks to her and takes the test and instructions efficiently.

INT. RUCHIKA'S LIVING ROOM, KUALA LUMPUR. - EVENING.

Aabidah embraces Ruchika on the floor of their apartment, rocking her gently and tight as Ruchika cries into her chest.

INT. RUCHIKA'S DOORWAY, KUALA LUMPUR. - EVENING.

Doreen knocks at the door. She holds concert tickets like a fan in front of her, hard but calm, as Ruchika opens the door.

Doreen sees how shattered Ruchika looks and her expression shifts, softens. Ruchika bursts into tears. Doreen catches her and holds her.

INT. CONCERT HALL TICKET DESK, KUALA LUMPUR. - MORNING.

Carosin purchases a ticket. She is nervous already, but looks much healthier.

INT. DOREEN'S BATHROOM, KUALA LUMPUR. - MIDDAY.

Ruchika sits in the bath. Doreen catches bath water in a jug and pours it over Ruchika's back, rinsing her hair and skin. She bathes her like a mother and child.

She sings lullabies to her in Bahasa Melayu.

INT. HOSTEL ROOM, KUALA LUMPUR - - AFTERNOON.

Carosin puts on her cleanest clothes and applies make up. It is a bizarre and distant thing to be attempting glamour by choice.

As she goes to leave her hostel room she reaches for the door handle. She looks down at her still hand in it's glove, frozen the moment before action.

EXT. CONCERT HALL, KUALA LUMPUR. - NIGHT.

A drop of blue dangling on the end of a finger.

Carosin stands across the road from the concert hall, anxious. 
She takes a deep breath and steps into the street.

INT. CONCERT HALL STAIRWAY, KUALA LUMPUR. - NIGHT.

Doreen and Ruchika's feet hit each step at the same time.

Doreen looks up at the seating directions. Red block to the left. Green block to the right.

\section{DOREEN}

Where are we seated?

Ruchika looks down at the tickets. The coloured dots are both blue to her. Ruchika's quiet optimism falters. Doreen cranes over, and, eager to keep the mood up, practically shouts -

\section{RED! Alright!}

DOREEN

She leads the way enthusiastically. There are swarms of people to navigate. Ruchika glances at the faces around her.

INT. CONCERT HALL STAIRWAY, KUALA LUMPUR. - NIGHT

Hundreds of people file in. Carosin is knocked about from side to side. She holds her ticket up to show someone scanning them at the threshold. The ticket attendant (16, female) looks unimpressed by the blue fingerprints all over the ticket but scans it all the same.

\section{Red area.}

TICKET ATTENDANT

She gestures a direction. Carosin follows, hesitant, feeling overwhelmed by the number of people.

INT. CONCERT HALL, KUALA LUMPUR. - NIGHT.

Carosin works her way to the front of the large crowd, squeezing through groups of friends, passing a couple who are trying to bite each other's noses. She gets near to the front just as the lights start to dim and tuning can be heard from backstage. Exciting!

CUT TO:

Much later, Carosin and Ruchika are both at the front of the crowd. They are separated by maybe twenty people but moving to the same beat. Ruchika smiles at Doreen beside her. 'Thankyou for this.' 
Carosin closes her eyes and dances in her own world for a little while. The music physically reverberates through her like a pulse. It moves through Ruchika too.

As if guided, Ruchika turns her head slowly to Doreen, and then to her other side. She sees Carosin.

Carosin opens her eyes, she can sense herself being watched. She turns. She sees. The music builds. They hold each other's eyes .

They each shift their whole bodies to face each other. They are too far apart to speak, there are too many people to move towards each other. Trapped.

They are bathed in lasers and lights as the music soars. A long moment of that sustained gaze. Carosin raises a hand meekly. Ruchika gulps and does the same.

Doreen, singing along and having the time of her life, notices this and touches Ruchika on the shoulder, trying to turn her back to the music. Doreen notices Carosin and there is a flicker of recognition.

The song picks up and people are jumping, Ruchika and Carosin have to move to keep sight of each other.

Ruchika pats Doreen's hand on her shoulder, reassuring her.

Carosin sees the hand, the shoulder, the closeness. Oh no.

Doreen turns back to the music. Carosin's heart drops.

The lights come up brighter and clearer and Carosin sees clearly that Ruchika's pupils have lightened, that they are the same cloudy blue as one of Geoffrey's eyes.

A look of sheer horror.

She drops out of sight, vanishing from Ruchika's view.

Ruchika moves to go after her, Doreen touches her arm, mouths over the overwhelming noise 'Are you alright?' Ruchika can't see anyone, she can't move. She is trapped. She nods.

Carosin squats as people dance around her, jolting her. She cradles her head in her hands. She cries out loud but the music mutes her. She pulls at her hair, she looks at her hands, tense and covered in blue ink, strained. She looks up at the lights. 'What have I done?' 
INT. AEROPLANE CABIN. - MORNING.

Carosin stares at her congealed hands. She flashes to Geoffrey's eyes, Ruchika's eyes. She shuts her own eyes. She mutters to herself -

CAROSIN

She's a fucking visual artist.

The passenger in the seat beside her eyes her suspiciously.

Excuse me miss?

The air steward (47, male) hands Carosin a form.

ATTENDANT V.O

Please make sure to fill out both

sides and declare anything

dangerous or contaminated that you

may be bringing to New Zealand.

Carosin nods and takes the form, wiping her hands on her trousers. She stares at the blotted, smudged ink on her legs.

INT. LIZZY'S CAR, DRIVING THROUGH CANTERBURY. - MIDDAY.

Carosin and Lizzy sit staring forward in silence.

EXT. MOTEL CARPARK, CANTERBURY - - AFTERNOON .

Lizzy is parked. Carosin looks puzzled, what are we doing here?

INT. LIZZY'S CAR, MOTEL CARPARK. - AFTERNOON.

$$
\text { You're in 3G. }
$$

Carosin looks outraged, 'What are we doing at a motel?'.

$$
\text { LIZZY }
$$

....with Geoffrey. You'll need to go to reception I expect.

Thanks.

\section{CAROSIN}

She gets out of the car. It is a grey day. She looks up at the grey motel. 
INT. MOTEL ROOM, CANTERBURY. - AFTERNOON.

Carosin throws her bag on a tidy single bed. The other has been slept in and is surrounded by clothes, the bedside table covered in tidbits.

Carosin sits down on the messy bed heavily. She hovers her hand an inch above Geoffrey's pillow, and strokes the air tenderly.

She looks down at her hand, hopeless. She starts to cry, makes a fist, frustrated. 'Fuck this. Fuck hurting people.'

INT. MOTEL KITCHENETTE, CANTERBURY - - AFTERNOON .

An element dial being turned to full.

Hands being washed under a kitchen tap.

The sound of frying meat.

Carosin stares down at the stove.

She exhales through the pain and closes her eyes.

Her hand, tense, the fingertips pushed down onto the ring.

Steam rising. A guttural, animal howl.

INT. MOTEL ROOM, CANTERBURY. - EVENING.

Carosin sits on the end of Geoffrey's bed.

She stares down at her hands.

Bubbling scar tissue and raw skin. She rebinds her fingers with non-abrasive binding, wincing.

CUT TO:

The lighting shifts. It is an hour later and still she sits.

Sandra and Geoffrey come in noisily.

They see her. They halt. She looks guilty. Sandra hesitates for a split second before going to Carosin and embracing her. She holds her tight. Carosin hugs back, although carefully, so as not to touch her hands to her mother's body.

Sandra draws away, her hands on Carosin's shoulders.

'Thank god you're safe'. She marches on to the kitchenette. 
SANDRA

You've been cooking? Smells

delicious.

Geoffrey stares. Carosin moves to hug him and he lets her, though he doesn't hug back. That's never happened before. As she pulls away he just stares and sits down on his bed.

SANDRA

We're so glad you're home darling.

You missed some big aftershocks!

We'll order a take away tonight to

celebrate you're home ay? Better

call your father straight away ay .

Carosin nods, glances at Geoffrey •

EXT. MOTEL STAIRWAY, CANTERBURY. - EVENING.

Rodney sees Lizzy pull up and Carosin get in as he tidies away the last of some pizza containers. He looks curious but relaxed. As he folds the boxes he calls out -

RODNEY

Home by midnight ay Caro?

Carosin nods. She blows him a kiss. He catches it.

INT. LIZZY'S BEDROOM, CANTERBURY. - EVENING.

Carosin and Lizzy are in bed, kissing. It is passionate but somehow clinical. Lizzy pauses.

LIZZY

You're grieving aren't you?

CAROSIN

Just fuck me.

LIZZY

Why?

CAROSIN

I need to be in my body.

Lizzy shifts away. 'That's not why I want this.' She begins to dress. 
INT. RUCHIKA'S BEDROOM, KUALA LUMPUR. - MORNING.

Ruchika squeezes her henna into a small pottle that already is half full with it.

She tapes a needle to a paint brush stem.

She dips the needle into the henna.

She unbinds her thigh gently.

The fingerprint is faint but remains.

She punctures the skin, marking herself with the needle, tracing the print.

She winces. She punctures again, and again. Her face is determined.

INT. ARTIST STUDIO, KUALA LUMPUR. - MIDDAY.

Ruchika sits by a brightly lit window doing her bridal Mehndi.

She blows on it, encouraging it to dry. She looks around.

She stretches her hands and admires her work, flips her hands and looks to weeping fingerprints. She looks to a blank canvas.

She approaches and cautiously begins to work in her own henna. She is relaxed, and paints fluidly. She crafts a likeness of herself, a woman covered in smudges and marks, showing an intimately placed fingerprint on her upper inner thigh. The print is clear and sweet.

Ruchika works for hours. The painting grows and grows. CUT TO:

Grubby and sweating, Ruchika stands back and admires her work. Her hands dangle at her sides. Her bridal Mehndi is dried and flaking. She itches it, and notices it flake.

She goes to wash it off rapidly and rebinds her fingertips once it is clean and crisp.

With fresh bound hands she takes out a large piece of packaging from the store room and carries it over to the canvas.

She dries the canvas with a hair dryer. 
She packages the painting. She writes the address. She pauses, considers, flips the package over and writes the Sender's address.

Switching the lights off, she carries the packaged painting with her as she leaves the studio.

INT. FAST FOOD CHAIN RESTAURANT, CANTERBURY - - EARLY MORNING. Carosin, in an uncomfortable polyester uniform, being shown around by a Manager. The manager points to things animatedly. She nods, numb. We see them from the exterior, the sound muffled.

INT. MOTEL ROOM, CANTERBURY. - NIGHT.

Carosin comes home, still in uniform, looking greasy. Geoffrey is in bed, reading a comic.

CAROSIN

It's a little late for you to be up isn't it?

Geoffrey doesn't respond. He reads pointedly.

CAROSIN

What's up little man? What'd I do?

GEOFFREY

It's been a while since you asked

that.

CAROSIN

Yeah well it's not easy when you're such a- [dick all the time]

GEOFFREY

I get it. Whatever.

Carosin walks into the bathroom, turns on the light, puts toothpaste on the brush. She speaks through her full mouth, brushing her teeth.

CAROSIN

It's not anyone's fault...

Geoffrey looks up to her, she leans in the bathroom doorway.

CAROSIN

Maybe Dad's... 


\author{
GEOFFREY \\ You think you know what everyone's \\ thinking, but that we have no idea \\ about you. \\ Carosin stops brushing, listens, focused.

GEOFFREY
I remember the day mum explained to
me that you were different, she
said it wasn't a big deal, that it
made no difference to our lives,
just that you were a little
special, that for some unknown
reason your hands acted in other
ways to mine.
But she was wrong. You are
different. Even though you
shouldn't be. It's not your hands
or the ink that make you so
isolated Caro it's how you fucking
treat everyone, like you're doing
us a favour just by being around,
like we couldn't possibly
understand.

He is angry now, his youth colouring his cheeks. Carosin is taken aback and spits out her toothpaste, but after a moment gathers momentum and superiority again.

You don't understand Geoffrey, you're just a kid still.

GEOFFREY

What? Understand that you kiss Lizzy? Understand that you're a liar? Understand that you're a lesbian what?

Shut it Geoff.

\title{
CAROSIN
}

\section{GEOFFREY}

But that's it! That's all you say! Shut it, shut up, shut off. You're closed off from everyone and it's all you Caro!

CAROSIN

That's not fair... 
GEOFFREY

It's not fair for anyone Caro, and

believe me it's not great being the

fucking little brother.

He stands, they are two meters apart or so now. He is breaking.

\section{GEOFFREY}

All I wanted was to be like you, I wanted you around and you kept this from me, kept me at a distance like you didn't even fucking trust me.

Carosin strides to where he is and hugs him. Tightly. She speaks softly to him, earnest -

$$
\text { I'm sorry. CAROSIN }
$$

She strokes the back of his head and he burrows his face into her shoulder. Her arms are tight around him, his hang loose.

\section{CAROSIN}

When will I get to keep something that I love?

She releases him, gently wiping the tears from under his eyes with her bandaged thumbs.

\section{GEOFFREY}

All you've got to do is show up.

All you have to be is there.

\section{CAROSIN}

When did you get so clever?

Her tone is still earnest, serious. She kisses him on the forehead and rests her forehead against his. They breathe together. She whispers to him -

\section{Thank you.}

CAROSIN

He shrugs off the intimate pose, still frustrated with her, and walks from her room.

She is alone.

EXT. MOTEL STAIRWAY, CANTERBURY - - NIGHT.

Geoffrey stands in his pyjamas with his back against the outside wall of the motel, breathing deeply. He wipes his face hastily. He places his hands over his eyes and exhales. 
He is trying not to have a panic attack.

INT. UPMARKET APARTMENT, KUALA LUMPUR - - AFTERNOON .

Zikri's hands are over Ruchika's eyes.

He takes them off, and looks enthusiastic, bobbing his head and grinning. Ruchika is puzzled.

Zikri holds up a 'Wait a minute!' finger and unlocks the door. He leads her in. She is still puzzled. It's a large empty apartment.

\section{This-}

ZIKRI

He gestures to the space.

$$
\text { - this is us! }
$$

\section{ZIKRI}

He smiles widely. Ruchika is shocked, her wide eyes apprehensive.

$$
\text { ... in three weeks! }
$$

He does excited hand gestures, Ruchika is even more horrified. She laughs almost hysterically, zikri takes it as a good sign!

Ruchika's face frozen in terror.

INT. HOSPITAL ROOM, HOSPITAL, KUALA LUMPUR. - AFTERNOON.

Ruchika's face frozen in terror.

Ruchika is receiving an early scan. Aabidah sits beside the bed, watching the apparatus dance slowly across Ruchika's stomach. Ruchika watches Aabidah watching.

Thank you.

RUCHIKA

Aabidah smiles weakly, uncomfortable.

Really

RUCHIKA 
A nurse enters (61, male). He nods to the Doctor (35, female) conducting the scan, who is using the keyboard to take snapshots on screen and as such is busy. The nurse directs his questions to Ruchika -

NURSE

I understand you've undergone some vision changes recently from the ingestion of a poisonous ink.

Ruchika, uncomfortable, nods hesitantly.

NURSE

Right. We've done some tests to see if your child will be physiologically affected.

Aabidah and Ruchika look at him expectantly.

NURSE

While vision is unlikely to be affected... it is likely that some pigmentation in the soft tissue may be altered.

'What does that mean?' The nurse gestures for each area. NURSE

Eyes, nail beds, lips, skin... possibly.

Ruchika and Aabidah look concerned.

NURSE
I wouldn't worry, it is still
likely your child will resemble
yourself and your husband more than
the cookie monster.

The joke doesn't land. The nurse leaves rapidly.

The Doctor makes eye contact with them, apologetic and a little embarrassed. Ruchika speaks softly, gazing at the white blue scan of her insides -

$$
\text { RUCHIKA }
$$

It'll be like it's her baby .

$$
\text { DOCTOR }
$$

The one who poisoned you?

A ripple. Ruchika nods. They all look to the screen. 
INT. RESTAURANT, CANTERBURY . - NIGHT.

Carosin and John sit across from each other at dinner. Carosin is highly constructed, wearing make-up and fitted clothing. John looks pleased and optimistic, cheery. They sit in awkward silence.

John reaches across the table and takes her hand, earnest -

$$
\begin{aligned}
& \text { JoHN } \\
& \text { I'm really, really glad you're } \\
& \text { home. }
\end{aligned}
$$

Carosin smiles politely. She touches his hand with both of hers, unbound. No mark is left. She smiles sadly and withdraws her hands.

INT. JOHN'S CAR, CANTERBURY. - NIGHT.

They are parked in the dimly lit Motel carpark. Carosin undoes her seat belt. John undoes his.

Carosin stares down at her bare hands. They have healed rapidly, the blue ink seeming to have fused the wounds, leaving her with faintly navy fingerprints, without moisture.

JOHN

That was awesome. Thanks for

tonight. I had a really sweet time.

Carosin looks at him and then up to her motel room. She stares at John's hopeful face hard for a few seconds.

She launches herself at him and kisses him hard.

Taken aback, he fumbles, and then kisses back, taking her head in his hands. She is leaning a long way. They do not pause. He guides her across and she clambers. Carosin is straddling him, she pauses.

$$
\text { I can be the right person for you. }
$$

She searches his eyes desperately. John nods and sputters -

$$
\begin{aligned}
& \text { JOHN } \\
& \text { I, I know, I'm really, I really } \\
& \text { want that. }
\end{aligned}
$$

She undoes his trousers. He halts her. 'Are you sure?' She dismisses it, kisses him again. She is urgent. She moves her underwear to one side and slides his penis into her. A look of relief. 
She puts her hands on his headrest and leans her head over his shoulder, staring out of the back of the car, at us. He groans and moves. She is still, numb, distant, unfulfilled. She winces slightly, her body moves with him, shuddering.

She does not stop him.

EXT. MOTEL WALKWAY, CANTERBURY • - NIGHT.

Carosin walks to her door, pulling her skirt further down as she walks. She glances in to her room. Geoffrey sits in bed playing solitaire with his headphones in. She smiles and is about to enter, when she hears Sandra in the room beside hers, on the phone, flirtatious and giggling. Carosin walks to just outside her parents door and leans to listen in. The spark isn't gone after all, Carosin smiles.

Footsteps coming up the stairway. Rodney, looking stressed, approaches the door with his keys ready. He smiles a sad smile at Carosin and pats her on the arm, then enters his room. Sandra hurriedly hangs up. Carosin stands, hollow and disgusted.

Fuck this family. Tension in her hands. She is furious. She notices Rodney has left the keys in the door by accident. A moment of decision. Carosin slides the keys out of the door and jogs down the Motel stairway.

INT. RUCHIKA'S APARTMENT, KUALA LUMPUR. - MORNING.

Zikri sits in a chair beside Ruchika's kitchen table, looking hopeful. He raises his eyebrows, questioning.

Ruchika sits across from him, looking downwards. She touches her stomach, her face. She is sweating.

RUCHIKA

We... when we...

She gestures vaguely to her bedroom.

Zikri grins at the memory, then grows concerned. 'What?'

$$
\text { I'm... }
$$

RUCHIKA

She shifts uncomfortably in her seat. She glances downwards again.

Zikri clicks and is overjoyed. He cheers and stands. He pulls Ruchika up and dances with her and then stops, worried he's being too careless with her. 
He steps back, placing his hands near her stomach as if warming them on an open fire. He rubs his hands together, excited.

ZIKRI

We need to get married!

Ruchika nods, trying to look optimistic.

\author{
Straight away! \\ ZIKRI \\ RUCHIKA \\ You're so happy. \\ ZIKRI \\ We are blessed oh thank you thank \\ you thank you!
}

He falls to his knees and worships at her feet. He kisses her stomach and then raises his eyes and hands to the sky.

He stands and does a little dance.

Ruchika is still. She watches him, her hands on her stomach.

INT. FAMILY CAR, DRIVING THROUGH CANTERBURY • - NIGHT.

Carosin stares straight ahead, driving fast down a rural road. She indicates and pulls off onto a residential, private dirt track.

EXT. CANTERBURY FIELDS. - NIGHT.

She walks. The grass crunches beneath her heeled shoes. She is still in her date outfit, with an additional oversized coat. She found it on the passengers seat of the car and it reads 'RODSTER' across the back in a racing car font.

EXT. HORSE BARN, CANTERBURY. - NIGHT.

She stands, limply holding some reins in her hand, the hood of her coat up. She is silhouetted by Betty's old barn, now totally engulfed in flame. Smoke rises into the still night.

The roar of the fire.

Silence. A long silence.

She twists the reins in her hands and pulls them tight. She closes her eyes and tilts her head back. 
She sees the swirl in Ruchika's hair. She see Ruchika's bright eyes and her smile lit by a camp fire. She keeps her eyes closed and pulls the reins tighter and tighter, until they cut off circulation.

She soaks in the glow of the fire. The whole barn burns. She pulls the reins until they quiver under the pressure.

Sirens in the distance startle her. She loosens the rein.

She runs hard.

INT. ARTIST STUDIO, KUALA LUMPUR. - EARLY MORNING.

Ruchika stands in front of a blank canvas.

She reads the labels on paint tubes until she finds Navy blue. She squeezes some out onto her palette, and unravels her bandaged hands.

She begins working, with her henna and the paint.

An hour passes as she creates arabic characters, henna patterns, sunrises and the suggestion of the curve of a woman's back, the shape of a running horse.

Doreen stands behind, having entered unseen. She watches silently, hopeful.

$$
\text { DOREEN }
$$

It is quite an incredible gift you've been given.

Ruchika is silent. She is surprised by Ruchika's presence but she doesn't turn.

\section{DOREEN}

To be able to put so much of yourself into everything you do.

Ruchika keeps working.

$$
\text { I love it. }
$$

$$
\text { RUCHIKA }
$$

Beat.

DOREEN

Who was that girl? At the concert.

Ruchika freezes, falters. She goes to keep working but cannot. 


\section{Carosin.}

\section{RUCHIKA}

Doreen is gentle, patient.

DOREEN

She was very beautiful.

Ruchika tilts her head. 'I know what you're trying to do.'

DOREEN

You don't have to tell me.

Her tone is kind but firm.

DOREEN

What you do have to do...

Ruchika turns to meet Doreen's eyes.

DOREEN

...you have to be my maid of

honour, at a makeshift wedding in a

community hall we're going to dress

to look like a temple. You have to

love my wife like you love me. You

have to be my friend. You have to

read me the news when I am old and

crotchety and can't see an inch in

front of my face.

And you have to acknowledge that I

can be a good Muslim and be in love

with Maria. That is what you have

to do, okay?

Ruchika is upset but tries to stay still and calm.

\section{DOREEN}

And I have to support your truth, whatever you decide it may be.

Ruchika calmly wipes her hands on a towel nearby and places it down. She is confident and holds her ground with Doreen for a long moment. Ruchika passes by her and leaves in silence.

Doreen sighs, believing that this is a lost hope. We see by Ruchika's face that she has heard Doreen, that she is accepting the gift Doreen is offering, just that she can't say it yet. Ruchika hears Carosin's voice as she exits - 


\section{I love you.}

CAROSIN $(\mathrm{V} \cdot \mathrm{O} \cdot)$

INT. POLICE CAR, DRIVING THROUGH CANTERBURY. - NIGHT.

Carosin is in the back. Numb. She stares out the window at the dark night. She leans her head against the window and almost goes to sleep.

A vision of Ruchika's face under an irrigation rig with her hair wet and love in her eyes. A wide smile as the water falls behind her.

Carosin opens her eyes slowly, sadly. She stares out into the night again.

INT. POLICE STATION HOLDING ROOM, CANTERBURY. - NIGHT.

A door with a glass panel closes and is locked from the outside. Carosin sits down on a long bench, beside a holding room mate; a 'bogan' woman with a stretcher below her lip. The cell is dimly lit, the woman nods to her.

CUT TO:

Later, they sit beside each other, unflinching. The woman's hand is up Carosin's dress. Carosin swallows, pleasure. The woman watches her face, smiling. Carosin keeps her eyes closed, her body reactive.

The sound of the reception door closing. Geoffrey and Lizzy enter the reception. Lizzy gestures Geoffrey to ask the lady at the reception about bail while she goes to look in on the holding room.

Lizzy starts off down the hallway to the holding room. Geoffrey remains in the reception area.

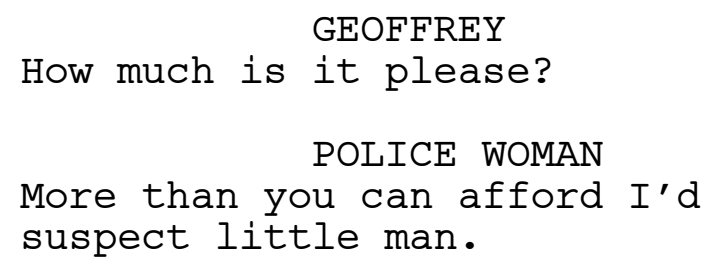

Geoffrey comes to ask Lizzy what to do, and stops by the door, where Lizzy stands frozen. She gulps. Geoffrey sees the shapes of his sister and the woman. His face drops, he gulps and he runs.

Lizzy sees him leaving out of the corner of her eye and is concerned, but she is transfixed. 
She snaps out of it and walks, furious, back to the reception.

Lizzy talks to the police woman, forms are filled out rapidly, she is frustrated. Lizzy mutters her agreement and hands over her credit card.

\section{LIZZY}

I guess I will save the day then.

Lizzy walks up to the holding room door again. The other woman sees Lizzy but continues regardless, grinning. Carosin has no idea. Lizzy unapologetically interrupts the two women, clearing her throat and banging a closed fist against the door. Carosin starts, surprised, and stands without looking at her holding room mate.

The police woman comes with the key, unlocks the holding room door. Carosin exits. The woman in the cell makes a sarcastic 'Call me' hand gesture as the door swings closed. Carosin smirks. The police woman frowns and pointedly locks the holding room again as Carosin and Lizzy exit through the reception.

INT. LIZZY'S CAR, DRIVING THROUGH CANTERBURY. - NIGHT.

Carosin and Lizzy stare forward, in silence.

EXT. MOTEL CARPARK, CANTERBURY . - NIGHT.

Carosin and Lizzy sit inside Lizzy's now stationary car in silence.

LIZZY

You ought to be careful who you're hurting.

CAROSIN

You know that's never what we were.

\section{LIZZY}

Grow up Caro. You're a fucking child.

Beat. Carosin shows no comprehension. Lizzy gestures to the Motel staircase where Geoffrey sits with his face buried in his curled up knees.

\section{LIZZY}

I meant him, you absolute bitch. 
Carosin clocks him, gets out of the car and closes the door. She begins to walk away, her hands in her coat pockets. The sound of Lizzy's car engine starting up.

Carosin feels something in her pocket. She takes out Rodney's keys. She stops, spins, walks back to Lizzy's car. She knocks on the window. Lizzy winds it down. Carosin leans in.

CAROSIN

Would you take me back to the barn?

Lizzy's expression reads 'Are you fucking serious?'

Please?

CAROSIN

It's for him.

Lizzy gestures to get in.

They pull away, fast.

INT. MOTEL ROOM, CANTERBURY - - NIGHT.

Sandra wakes with the noise of the car pulling away at speed, and sits up in bed.

She crosses the room and looks through the curtains. She sees Geoffrey outside on the stairway, still with his head to his knees, curled up.

EXT. MOTEL STAIRWAY, CANTERBURY • - NIGHT.

Sandra sits down beside Geoffrey on the staircase and cuddles him in under her arm. He begins to cry. She strokes his hair and kisses the top of his head.

INT. RUCHIKA'S APARTMENT, KUALA LUMPUR. - MORNING.

Ruchika gets home and closes the door behind her. She leans again it and sighs.

She checks if Aabidah is home by listening intently for a few seconds. No sound.

She takes a deep breath and let's out a low growl, which builds to a yell. She punches the wall, slams her feet into the ground. There is fire in her.

She stamps into the middle of the living room. She takes off her gloves and punches one hand into the other. She slaps her own body up and down. 
She moves her bare, rapid hands down her legs to her feet. She sits on the floor, pulling at her own hair, fingers, toes. She grabs the second toe of each foot and pulls. She places both hands on the second toe of one foot. She pulls. She puts all her pain and confusion into the pull.

We see her focus hard. We see her face in pain.

We hear the snap of her toe breaking.

We see the reaction, snap shot before yelling 'FUCK!'

EXT. BURNT DOWN BARN, CANTERBURY. - JUST BEFORE DAWN.

A car door slams shut. Carosin waves her thanks to Lizzy.

Lizzy drives away fast, shaking her head. Good riddance Carosin Thomas.

Carosin crosses to her parents' car. She walks barefoot, heels in hand. She stares sideways at the burnt out barn, a wreck. She walks towards it, takes a piece of charcoal from the ruin. She smells it and draws war stripes on each cheek. She kisses it softly and eats it.

INT. CAR, DRIVING THROUGH CANTERBURY. - JUST BEFORE DAWN.

Carosin is driving through countryside, fast. She looks at herself in the rear view mirror.

'We're doing this'.

INT. PRIYA AND AISAR'S APARTMENT, KUALA LUMPUR. - MIDDAY.

Ruchika carefully dresses in her wedding clothes as Aabidah assists her in silence. Priya buzzes around the pair, fretting.

Ruchika hides her fingerprint tattoo from Aabidah by closing her legs tight when she assists with lowering her exquisite dress over her head.

\section{PRIYA (BAHASA MELAYU)}

Ruchika always rushing! Rushing Ruchika! That's what we should call you. I don't understand it!

Aabidah adjusts the base of Ruchika's dress and fans it out, staring subconsciously at Ruchika's stomach. She meets Ruchika's eyes, and stays silent. Ruchika's gaze speaks her thanks. She speaks to Priya, softly, defeated - 
Why wait?

RUCHIKA

EXT. TRAINING GROUND, CANTERBURY. - JUST BEFORE DAWN.

The car door slams closed. Carosin stands beside the car, focused. She takes a deep breath. 'I am ready'. She take a long step forward, but her tight dress constricts her. She stops.

Carosin strips to her underwear and puts the 'RODSTER' coat back on. She steps out of her dress, which is left on the muddy ground.

She pulls a spliff from her pocket, and lights it. She takes a drag, and feels something cold on her foot. She looks down. She see a tiny snail crawling across her foot, leaving it's silvery track. Tenderly and carefully, she picks it up. She holds it in front of her face and gently touches the end of each of it's antennae with her finger. The antennae shoot into the snail's head. She smiles.

She places the snail gently down on her discarded dress.

Carosin smokes her spliff as she leans against the hood of her car. She stands beside her dress, the snail still there. They are silhouetted in the half-light of just-before-dawn, facing a high fence. Carosin looks to the snail, to the fence, and walks forward.

Carosin meets the high fence. She stubs out her spliff on a panel and drops it to the earth below her still bare feet. She jumps high, catches the top of the fence and, with great effort, pulls herself upwards.

She scrambles, strong, and eventually swings her legs over the top of the fence.

She sits atop the fence and gazes at the large training ground. Across the barren mud, looking out from a stable, Carosin sees Betty.

A broad smile breaks out on her face. She leaps down from the wall.

INT. MOSQUE, CENTRAL KUALA LUMPUR. - EARLY AFTERNOON.

The sound of a cushion hitting the floor hard. The noise comes from the back of the room. Aabidah, standing beside the cushion in question, looks faux-apologetic. 
Ruchika sits in her ornate wedding dress at the front of the room. Her marriage solemnization begins. She fidgets. She puts her hands to her face, then to her lap, then to her legs.

She looks to her thigh. She pushes the silken fabric down and feels for her still scabbing tattoo beneath the smooth material.

She takes a deep breath and closes her eyes, clasping her hands in her lap.

She sees a hand-drawn flipbook animation of Carosin's smile, her crossed over front teeth. Ruchika smiles, her eyes still closed.

Priya leans in, whispers in Ruchika's ear.

PRIYA

Good luck my daughter.

Ruchika starts, opening her eyes. She smiles her thanks. She mouths the word 'luck' to herself.

She makes a decision. She looks at her mother as Priya politely backs away.

Ruchika softly excuses herself.

Zikri watches her from his seat beside hers, panicked. He looks to Aisar, who stares, furious. They are so shocked that no one follows her. She walks, then jogs, out of the space.

As she walks out of the mosque she puts her hands to her head, the relief is dizzying and she feels sick.

INT. MOSQUE HALLWAY, KUALA LUMPUR. - AFTERNOON.

Zikri and Aisar angrily follow after Ruchika.

EXT. MOSQUE, KUALA LUMPUR. - AFTERNOON.

When Ruchika exits the Mosque, and looks out to the world outside the Mosque grounds, she sees Doreen on the pavement, incognito, wearing a hijab and large retro sunglasses.

Ruchika jogs to her, carrying her skirt to keep it up off the ground. They embrace. They run from the mosque, just as Aisar, Priya and Zikri emerge looking confused and angry. They just miss Ruchika. 
EXT. STREET, CENTRAL KUALA LUMPUR. - AFTERNOON.

Further down the road, Doreen grabs Ruchika's hand in solidarity as they run together. Ruchika's eyes well with the relief and support.

EXT. CANTERBURY FIELDS. - DAWN .

Carosin gallops on Betty, letting out a cry of relief.

They are exhilarated. They leap a fence onto a dirt track, and canter along the road.

INT. CORRIDOR OUTSIDE RUCHIKA'S APARTMENT, KL. - AFTERNOON.

Ruchika and Doreen, still dressed in a wedding dress and a modest burqa, rapidly transport Ruchika's belongings from her apartment to Doreen's.

They shift her cumbersome mattress between them.

INT. RUCHIKA'S APARTMENT, KUALA LUMPUR. - AFTERNOON.

Ruchika rushes to pick up the last of her possessions. She pauses a moment, taking stock.

Doreen enters behind her. Beat.

Doreen carries Ruchika's foodstuffs in her arms and Ruchika picks up a large stack of her clothes, folding them over her arm.

\section{DOREEN}

Is that all of it?

Ruchika nods and places her key on the table.

Oh! Unzip me?

RUCHIKA

Doreen carefully unzips Ruchika's wedding dress. Ruchika sheds the dress and covers the under-slip with a dressing gown left on the back of the sofa. She holds the dress for a moment, caresses it and gently hangs the dress on the back of a seat at the kitchen table.

\section{RUCHIKA}

That's everything.

They hear feet coming up the stairs, and aggressively spoken Bahasa Melayu, from far below. 
They carry the last of Ruchika's things and slip out of the door. It closes slowly by itself.

We stay focused on the closed door. A few moments pass.

A fist hammers at the door.

Ruchika!

AISAR (BAHASA MELAYU)

PRIYA (BAHASA MELAYU)

Let us in Ruchika.

They mutter angrily.

INT. CORRIDOR OUTSIDE RUCHIKA'S APARTMENT, KL. - AFTERNOON. Zikri kneels at the keyhole, glancing at Priya and Aisar.

ZIKRI

Ruchika, please talk to me.

INT. DOORWAY, DOREEN'S APARTMENT, KUALA LUMPUR - - AFTERNOON. Ruchika leans back against the door. She closes her eyes.

I love you.

$$
\text { ZIKRI (O.S.) }
$$

Please.

Ruchika mouths 'I love you too.'

Doreen sits at her kitchen table, surrounded by Ruchika's belongings in chaotic piles, frozen.

Silence.

Aisar and Priya, muttering their frustration loudly, decide that she is elsewhere. They move quickly down the stairs.

\section{Ruchika?}

ZIKRI (O.S. MUCH CLOSER)

Ruchika jumps, banging her head on the door.

INT. HALLWAY OUTSIDE DOREEN'S APARTMENT, KL - - AFTERNOON.

Zikri reacts, having heard the jolt. He presses his palms to the door as if in prayer, his face at Doreen's keyhole. He leans his head against the door, his knees on the doormat. 
INT. DOORWAY, DOREEN'S APARTMENT, KUALA LUMPUR. - AFTERNOON.

Ruchika moves away from the door, crouches and wipes her eyes with the backs of her hands.

She looks out through the key hole.

\section{KEYHOLE •}

The Keyhole is covered briefly, as zikri's hand passes over it.

INT. HALLWAY OUTSIDE DOREEN'S APARTMENT, KL. - AFTERNOON .

Zikri's hand passes over the keyhole. His head is bowed.

Aabidah comes running up the stairs behind him, sweating and breathless.

She regains composure and touches Zikri's back lightly. He look up at her.

Aabidah opens her apartment door. Zikri follows her in, still searching.

$$
\begin{aligned}
& \text { ZIKRI } \\
& \text { Ruchika? Rooshy? }
\end{aligned}
$$

INT. AABIDAH'S APARTMENT, KUALA LUMPUR. - AFTERNOON.

Aabidah and Zikri stand in the doorway to Ruchika's bedroom, shell-shocked. They gaze at the empty, open drawers, the vacant bed base, the barren side table.

Zikri puts a hand to his face, shakes his head. No. Please. Aabidah looks up at him.

$$
\text { I love you. }
$$

AABIDAH

A long moment of silence. Zikri drops the hand from his face. He looks at Aabidah, his expression vacant. He goes to place a comforting hand on her back. He changes his mind.

Zikri stares forward. Aabidah stares at Zikri. 
EXT. MOTEL CARPARK, CANTERBURY - - DAWN.

Carosin sits atop Betty in the carpark, dishevelled.

EXT. MOTEL WALKWAY, CANTERBURY • - DAWN .

Carosin walks along the walkway outside her room, slipping her key into the door of her motel room.

She opens the door and peers in. Geoffrey's bed is empty.

INT. PARENTS' MOTEL ROOM, CANTERBURY - DAWN.

Carosin gently enters her parents' motel room with Rodney's keys and sees Geoffrey in bed with their parents. He is asleep next to Sandra, huddled up like a child.

Carosin stops to admire them there.

She walks around the bed cautiously and gently shakes Geoffrey awake. He blearily opens his eyes. Carosin covers his mouth with her hand and, slowly waking, Geoffrey cautiously rises.

INT. MOTEL ROOM, CANTERBURY - - DAWN .

She sneaks back into their shared room and finds a pair of Geoffrey's shoes and a coat for him to wear.

Halting at the door, she reconsiders her own apparel and slips into a pair of jeans. She ties her sneakers while sitting on the end of her bed.

EXT. MOTEL STAIRWAY, CANTERBURY. - DAWN •

Geoffrey meets her outside, gently closing the door to their parents' room. He accepts his belongings from Carosin and slips on his coat. He sits at the top of the stairway to do up his shoes.

Carosin jogs past him down the stairway.

EXT. MOTEL CARPARK, CANTERBURY - - DAWN

Carosin leads Betty out into the middle of the carpark.

When Geoffrey sees Betty, he instantly wakes up, and runs down to her. 
Carosin holds her at the reins, and nods Geoffrey to climb up. He clambers, his legs dangling and kicking. Carosin grabs one of his feet and gives him a leg up, propping him so that he can swing his other leg over. He sits atop Betty in the cool dawn light.

Carosin stands back for a second and admires him there, proud. She squeezes her eyes shut hard for a second.

When she opens them again, Geoffrey is pulling a grotesque face and laughing.

\section{CAROSIN \\ Shut it you.}

She pulls herself up behind him and they set off, trotting out of the carpark.

$$
\text { GEOFFREY }
$$

Thank you.

Beat.

$$
\begin{gathered}
\text { CAROSIN } \\
\text { I'm really sorry Geoffrey. } \\
\text { I really mean it. } \\
\text { GEOFFREY } \\
\text { You showed up. }
\end{gathered}
$$

He smiles without turning. She scruffs his hair. They move into a canter.

EXT. RURAL ROAD, CANTERBURY - - SUNRISE.

Carosin and Geoffrey trot along on Betty's back as the sun rises. They are silhouetted like old-time cowboys.

Geoffrey spreads his arms wide, like Rose at the front of the Titanic. Carosin jabs his ribs. He pulls his arms back in.

EXT. CANTERBURY FIELDS. - EARLY MORNING.

Carosin stands in an anonymous field as Geoffrey canters around, free and happy. He is joyful.

She waves to him and he approaches. He looks fresher and younger and lighter. Carosin kisses Betty on the nose. 
Geoffrey smiles down at her. Carosin mounts Betty, swinging herself up behind Geoffrey and clicks her tongue.

Betty breaks into a trot.

EXT. TRAINING GROUND, CANTERBURY. - EARLY MORNING.

Carosin and Geoffrey trot up to the gates of the training ground. Carosin jumps down from Betty's back and walks a few steps, before repeating her fence climb.

Geoffrey struggles to dismount. He breaths deeply and drops to the ground. A long silent moment, he glances about him but Carosin is nowhere to be seen. Geoffrey begins to wonder.

The gates of the training ground open, and Geoffrey leads Betty towards them. When he is almost through the gate with Betty, Carosin halts Geoffrey with a raised hand.

She jogs to the car and quickly creates a make shift sign out of a piece of cardboard and some wire.

She writes on it in permanent marker and runs back to Geoffrey, dangling the sign around Betty's neck.

She kisses Betty on the cheek and hands Geoffrey the reins.

EXT. TRAINING GROUND, CANTERBURY. - EARLY MORNING.

Geoffrey leads Betty into her stall. Carosin secures the sliding bolt.

EXT. TRAINING GROUND, CANTERBURY. - EARLY MORNING.

Carosin and Geoffrey walk out of the gate, closing it behind them.

INT. FAMILY CAR, DRIVING THROUGH CANTERBURY. - EARLY MORNING.

Carosin drives. Geoffrey sits in the passenger seat, asleep.

Carosin looks over to him. She is really happy. She wipes her eyes. It was good to say a proper goodbye.

INT. TRAINING GROUND STALL, CANTERBURY. - EARLY MORNING. Betty stands in her stall bearing the sign, which reads; YOU'RE NOT MY REAL MUM AND DAD! 
INT. PRIYA AND AISAR'S APARTMENT, KUALA LUMPUR. - MIDDAY.

Ruchika sits on the sofa, stiff and anxious.

Her parents sit in two identical arms chairs, facing her.

Zikri sits to one side.

Aisar's eyes. Priya's eyes. Zikri's eyes.

They all stare at Ruchika, intently focused and judgmental.

AISAR (BAHASA MELAYU)

I'm sure we don't need to tell you

how inconvenient this has been.

PRIYA (BAHASA MELAYU)

We are all very hurt by what you

have done.

Ruchika looks meek, shakes her head.

\section{May I...}

ZIKRI (BAHASA MELAYU)

He looks to Aisar for permission. Aisar's expression is blank. Zikri turns his focus back to Ruchika.

ZIKRI

I forgive you.

I want to get married.

Still.

A long pause.

ZIKRI

I understand... you were nervous, overwhelmed, we rushed everything. We can wait... not very long, but... a little, if it will help.

Almost too quiet to hear, Ruchika replies -

$$
\text { Zikri... }
$$

RUCHIKA

Zikri is attentive, interested.

$$
\text { ZIKRI }
$$

Please.

RUCHIKA

... I'm so sorry. 
ZIKRI

I told you I'm not angry!

Ruchika looks to her parents.

I am loved.

Everyone nods.

RUCHIKA (BAHASA MELAYU)

And I love in return.

zikri nods his relief. Finally.

RUCHIKA (BAHASA MELAYU)

But she is not here.

Silence. Beat.

Aisar's eyes. Priya's eyes. Zikri's eyes.

They all narrow, angry and confused.

AISAR (BAHASA MELAYU)

Stop playing around Ruchika there is no time.

Ruchika is more resolute -

I'm not playing.

RUCHIKA (BAHASA MELAYU)

My Rushy-

PRIYA (BAHASA MELAYU)

RUCHIKA (BAHASA MELAYU)

I'm not your Rushy, I'm sorry.

I am hers.

I am marked in love and,

I can't... not be.

Aisar stands, aggressive, impatient.

Get out.

AISAR (BAHASA MELAYU)

Ruchika's eyes plead with him.

AISAR

You are talking nonsense, and you are disrespecting us all. 
ZIKRI

Just go Ruchika.

You don't want any of us.

Ruchika looks to Priya, who turns away.

Ruchika looks to the door.

INT. DOREEN'S APARTMENT, KUALA LUMPUR. - AFTERNOON.

Doreen's apartment door.

The sounds of clattering and tidying.

Ruchika stares at the door. She closes her eyes.

A hand-drawn flipbook animation of Carosin breaking through the door and standing, backlit in the frame, a victorious silhouette. She steps forward into the light, and moves towards Ruchika, arms extended. Carosin mouths 'It's okay!'

CLICK. Doreen's fingers, just clicked, hover in front of Ruchika's face. Ruchika turns back to the front and continues eating her dry cereal dejectedly. Doreen reaches across and holds her hand briefly. Ruchika's fingertips are unbound. They weep.

CUT TO:

Later, Ruchika tidying while Doreen reads a book. CUT TO:

Later, Ruchika in the bath staring at the ceiling. CUT TO:

Later, Ruchika sketching a flipbook of a rider and horse galloping across a page, while Doreen cooks, humming a Gwendolyn Prair song.

CUT TO:

Doreen and Ruchika pray together in Doreen's lounge. CUT TO:

Later, Ruchika and Doreen sit at the kitchen table. Ruchika picks at her food, moving it around her plate but not touching it. Doreen eats hungrily.

DOREEN

You know, it's mostly a matter of getting through this part.

(MORE) 
DOREEN (CONT'D)

And the part later, you're going to

be like 'WOW! This is amazing!'.

It's like Disneyland, but for

lesbians.

Ruchika smiles, somewhat heartened.

DOREEN

You can't look so bloody miserable

for my wedding anyway, yeah?

Ruchika takes a bite of her meal.

EXT. LIFESTYLE BLOCK, CANTERBURY. - MORNING.

Mena approaches a large, square, flat package at her doorstep, curious.

INT. LIFESTYLE BLOCK, CANTERBURY. - MORNING.

Mena enters. She carries the large package down a long corridor to show it to Pascal. Together they inspect the box and exclaim majestically, having fun with the mystery.

Mena tilts her head, reading a small note written on the parcel. She exclaims, raising her hands. She carries the parcel back down the long corridor and out of the house again.

EXT. CAROSIN'S HOME, CANTERBURY. - MORNING.

Mena pulls up, takes the canvas from the boot of her car and leans it up against the large entryway. She rings the bell like a naughty child, runs back to her car and speeds away.

She checks the rear view. There is no one there.

The package sits by the door, utterly bereft of mischief.

INT. MOTEL KITCHENETTE, CANTERBURY. - MIDDAY.

Carosin and Geoffrey cook bacon and eggs in the cramped kitchenette. Carosin hears a honk.

She glances past thin net curtains that she pulls to one side.

Below in the carpark, Lizzy leans against the hood of her car. 
Carosin leaves Geoffrey cooking, scruffing his hair as she exits. He pretends it annoys him and smooths his hair down, but he smiles once she's gone.

EXT. TRAMPOLINE AT MOTEL, CANTERBURY. - MIDDAY.

Carosin and Lizzy lie beside each other on the rusty trampoline to the side of the Motel courtyard. Carosin looks content lying with her arms over her face. She hasn't noticed Lizzy's sour expression.

\section{CAROSIN}

Thank you so much, for everything. That was a big night... I can pay you back.

Lizzy, frosty, leans on her elbows, staring down at Carosin.

LIZZY

Don't worry about it, Mark just got

a bonus.

$$
\text { CAROSIN }
$$

How is Marvellous Mark?

$$
\text { LIZZY }
$$

Selfish...

But he means well.

$$
\begin{aligned}
& \text { That's good. } \\
& \text { It's more than you are kid. } \\
& \text { Carosin nods her head to the side. 'That's probably fair.' } \\
& \text { Carosin leans up on her elbows too. }
\end{aligned}
$$

CAROSIN

I think I might be starting. To be better. A bit.

A moment of kind and connected eye contact. Lizzy leans in to kiss Carosin.

\section{CAROSIN}

Don't. I... I can't. I'm sorry. There's no room...

\section{LIZZY}

I've done everything for you Carosin. 
CAROSIN

I can't.

Beat.

Fuck you.

LIZZY

Lizzy stands up, pauses and then jumps once, hard, to bounce Carosin on the trampoline. Carosin looks confused.

Fuck you.

Lizzy storms off. Carosin sits up. 'What the fuck?'

INT. PARENTS' MOTEL ROOM, CANTERBURY. - MIDDAY.

Geoffrey sits on the end of his parents bed. Rodney and Sandra, still in their pyjamas, sit up in bed. They are all eating bacon and egg butties. Another full plate sits beside the television, for Carosin.

Sandra speaks through a full mouth -

SANDRA

Poppy reckons it's a formality

though, she said that Laura's

really happy with my work so far,

so that's good.

RODNEY

That's brilliant! Well done!

I'll drop you to work?

Sandra nods, finishing her breakfast and hopping out of bed. Rodney throws back the sheets to get out of bed too.

LIZZY

Your daughter...

All heads turn to Lizzy, standing in the doorway. She has a hand on each side of the door frame, full of angry energy.

LIZZY

...she's been lying to you!

Geoffrey stands up, defiant.

LIZZY

Sorry

She is clearly not sorry. 
RODNEY

What are you on about Lizzy?

Lizzy looks at each of their faces. She drops her arms, tense, and relaxes her hands.

$$
\text { She's... LIZZY }
$$

She nervously pushed her wedding ring around her finger with her left thumb, as if it itches her.

$$
\text { She's just a liar, that's all. }
$$

Rodney and Sandra stand silent, incredulous. Geoffrey speaks, authoritatively -

GEOFFREY

Get the fuck out Lizzy.

A moment. She leaves.

EXT. MOTEL STAIRWAY, CANTERBURY • - MORNING. Carosin crosses Lizzy on the stairs, still baffled.

INT. PARENTS' MOTEL ROOM, CANTERBURY. - MORNING.

Carosin steps through the doorway. All eyes are on her.

What?

CAROSIN

$$
\begin{gathered}
\text { SANDRA } \\
\text { Lizzy says you've been... } \\
\text { GEOFFREY } \\
\text { It's okay Caro. I know. } \\
\text { CAROSIN } \\
\text { She say's I've been what? } \\
\text { Lying? About what? } \\
\text { GEOFFREY } \\
\text { She's gay. }
\end{gathered}
$$




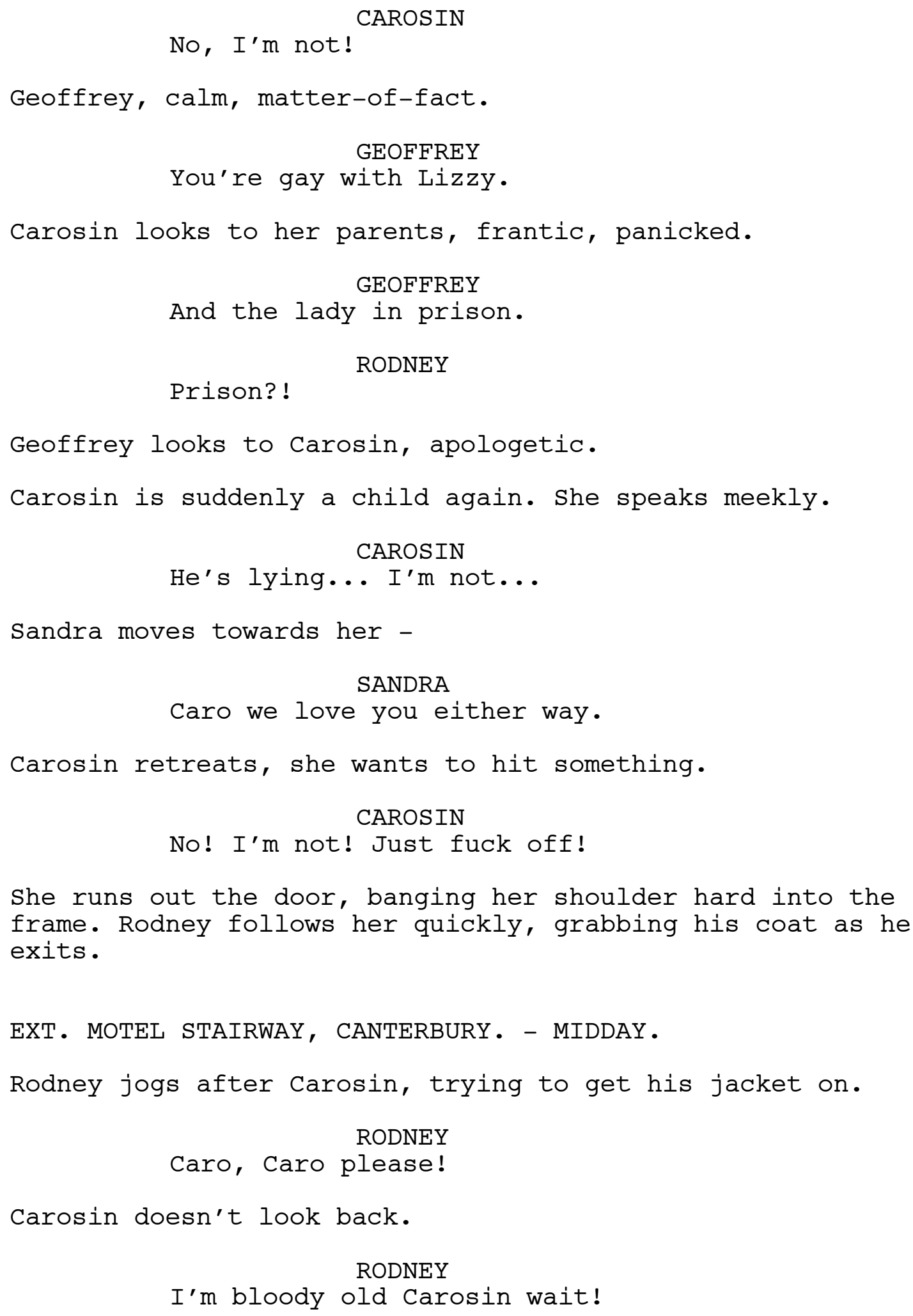


INT. PARENTS' MOTEL ROOM, CANTERBURY. - MIDDAY.

Geoffrey and Sandra are left alone.

Geoffrey looks very guilty. Sandra pulls him into a hug.

SANDRA

She doesn't mean it Geoff.

You'll... we'll be fine.

She looks out the window as she cradles him. She kisses the top of his head.

EXT. ROAD NEAR THE MOTEL, CANTERBURY. - MORNING.

Carosin leans against a fence a little way down the road from the Motel. She is panicked, like a spooked horse.

Rodney approaches from a distance, puffed and sweating. As he walks, he stops a few metres away from Carosin and bends, his hands on his knees, catching his breath.

After a moment he stands up, still watching her, and takes a pack of cigarettes from his coat pocket.

He walks the last few meters to her and, cigarette in one hand, hesitates, before putting his other hand on her back. She tries to sniff through, and wipe away, her obvious tears and anxiety. She turns to lean against the fence, rolling her tongue around her mouth.

CAROSIN

It's not true Dad. He's lying. It's

a lie. She's just angry at me.

She's gay, she tried to kiss me.

RODNEY

Nothing to worry about then I suppose.

Carosin, noticing the cigarette -

CAROSIN

You smoke?

Rodney flicks the ash off the end of his cigarette.

RODNEY

I guess that's one less secret.

CAROSIN

I preferred not knowing. 
RODNEY

No. You just think you did.

A long moment passes.

RODNEY

You're the bravest person I know

Caro, always have been, and I think

it's about time that you admitted

to yourself how brave you are.

Carosin listens.

RODNEY

Your mother and I have been in

love, believe it or not, for twenty

seven years. We both thought you'd

gone away out of hate. Hate for us.

You can't imagine what a relief it

would be to know love took you

away. To think love made you run.

Love fucks us all up a bit, and I can only imagine how scary it is in

a little town like ours to love

differently. But, at the end of the

day, it's not different at all.

It's just love. The same love we

have for you. The same love you'll

have for your kids...

He chuckles to himself -

RODNEY

Hopefully not quite the same love

but, you catch my drift ay.

Carosin stares at her father. Her face crumbles. Daddy. He pulls her into an embrace, his arms tight around her sobbing head. His cigarette singes a little of her hair, he moves it away, and throws it to the ground. One of his hands hold Carosin's head, hard. He plants a light kiss on her temple.

RODNEY

We're not going anywhere okay.

And no more secrets.

He is clinging to her too. 
INT. MOTEL ROOM, CANTERBURY. - AFTERNOON.

Carosin sits on Geoffrey's bed with him. They play cards in silence. She wipes her nose on her sleeve, which is so long tat it covers and obscures her hand. She is somehow more relaxed, as if her pulse has slowed.

Geoffrey watches her, cautious -

$$
\begin{array}{r}
\text { GEOFFREY } \\
\text { I'm sorry I said it. } \\
\text { CAROSIN }
\end{array}
$$

It's okay, I know it came from a good place you little shit.

GEOFFREY
I've known for ages.

Carosin raises her eyebrows.

\section{CAROSIN}

That makes one of us Geoff.

GEOFFREY

I only didn't say cause I was

waiting for you to tell me.

Carosin runs her hand down Geoffrey's whole face, smushing it.

CAROSIN

You're like, a real solid brother.

Geoffrey grins, proud of himself.

GEOFFREY

If you met a boy like me would you

still be gay?

Carosin wipes the hand she touched him with on her leg, grossed out.

$$
\begin{gathered}
\text { CAROSIN } \\
\text { You're so weird Geoff. }
\end{gathered}
$$

Geoffrey grins even wider. 'That's more like it.'

Carosin checks her watch.

$$
\text { Oh shit! }
$$

CAROSIN

She jumps up from the bed. 


\section{Look away!}

\section{CAROSIN}

Geoffrey covers his eyes immediately. Carosin rapidly changes into her fast food uniform. She rushes through the door, Geoffrey calls out after her -

SNACKS CARO!

GEOFFREY

INT. ART GALLERY, KUALA LUMPUR. - MIDDAY.

Ruchika is at the desk while Doreen repositions a painting slightly.

Ruchika sees a young teen girl looking at a postcard of a print of one of her paintings; a woman's figure in deep red, elegant and strong. The kid glances at Ruchika, before pretending to put it back, but actually slipping it into her pocket.

Ruchika pretends she didn't see. The kid knows. The kid smiles. Doreen interjects -

\section{Oi!}

DOREEN

The kid runs, Doreen runs after her but by the time she reaches the door Doreen is laughing.

\section{Little scamps!}

DOREEN

She goes back to her work, Ruchika smiles out at the road.

INT. MOTEL ROOM, CANTERBURY. - LATE NIGHT.

Carosin returns home, exhausted, and flops onto her bed. She groans limply. Geoffrey is sat up in bed, reading a comic by light of the lamp. He dons a low and authoritative voice -

$$
\text { GEOFFREY }
$$

You bring me a snack woman?

Carosin squirms, and pulls a burger out of her pocket. She throws it at his bed without sitting up. She groans again.

INT. MOTEL ROOM, CANTERBURY. - MORNING.

Sandra gently shakes Carosin awake. 
SANDRA

Come on love, it's time.

INT. FAMILY CAR, DRIVING THROUGH CANTERBURY. - MORNING.

Carosin and Geoffrey play slaps in the back seat. He slaps her hard. She slaps back harder and winces.

Her fingertip, split slightly, has some blue congealed ink weeping through.

Silently Geoffrey digs around for the first aid kit as Carosin sucks on her fingertip, trying not to cry from the sting.

Geoffrey takes her hand and delicately dresses the wound, applying pressure as he binds it. He touches another

fingertip. He speaks quietly -

$$
\begin{aligned}
& \text { GEOFFREY } \\
& \text { When did you do that? }
\end{aligned}
$$

Carosin holds his eye contact.

EXT. BURNT DOWN BARN, CANTERBURY. - MORNING.

Rodney and Carosin stand in the middle of the wreckage of the burnt out barn. They look around. Carosin looks to the sky through what used to be the roof of the barn.

$$
\begin{aligned}
& \text { CAROSIN } \\
& \text { I'm sorry I burnt this down. } \\
& \text { RODNEY } \\
& \text { I poured the gasoline before you } \\
& \text { lit the spark kiddo. }
\end{aligned}
$$

Sandra walks from the car and puts an arm around Carosin. Carosin leans into her, accepting the embrace.

Geoffrey runs over with a blanket and a cooler and begins to set up the picnic behind his family. Carosin smiles, watching him. Her eye catches something coming up the road. She nudges Rodney •

A car drives up with a large picture of a woman's face (26) on the side of it, and the slogan 'MOST SUCCESSFUL SELLER 2009' emblazoned upon it. An Evaluator (Female, clearly aged since the accolade) approaches.

As she arrives, they are sitting down to eat. 


\section{EVALUATOR \\ Sorry to interrupt-}

Rodney stands.

\section{RODNEY}

Are you? Because if you are, just don't.

The Evaluator is so taken aback that she can only sputter.

RODNEY

Excellent! Come back tomorrow.

I appreciate it.

Bewildered, she simply walks away •

She drives away, still baffled.

The family laugh as they sit and eat apples and budget cheese and marmite sandwiches.

\section{SANDRA}

I understand if you don't want to say, but who is she?

Carosin gets a secret smile on her face. Sandra and Rodney share a glance, 'Okay so it's a romance'.

\section{GEOFFREY \\ So you're in love with her?}

Carosin, although she can't quite believe this conversation is happening, shrugs, smiles, nods, her mouth full of apple.

Rodney looks to Sandra, Sandra nods back.

$$
\text { RODNEY }
$$

Look Caro... we don't have a lot, but we have enough, if you want to not give up on this... on her...

Carosin shakes her head, her expression saddening. Sandra and Rodney look to each other.

INT. DOREEN'S APARTMENT, KUALA LUMPUR. - NIGHT.

Ruchika sits beside Doreen on the sofa, completing her wedding henna. Doreen is nervous, shifting in her seat. Ruchika smiles, trying not to be too introspective.

RUCHIKA

\section{All done.}


Doreen gives a watery smile, worried.

RUCHIKA

You're going to look so beautiful!

This is the scary part right?

The rest... magic.

Doreen nods and breathes deeply. Her eyes fog up. Ruchika hushes her and hugs her. Doreen elevates her freshly hennaed arms once again.

EXT. CAROSIN'S HOME, CANTERBURY. - MIDDAY.

Geoffrey walks around the front of the house pretending to be a jedi with a big stick that he waves around like a

lightsaber, even making sound effects.

He sees the package. He tilts his head. He pretends it is a threat and approaches it like a dangerous animal, eventually whacking it.

It falls forward slowly until it hits the dust. He feels guilty. He picks it up, inspecting it, curious.

EXT. CANTERBURY FIELDS. - MIDDAY.

Geoffrey approaches Carosin, Sandra and Rodney, who are playing frisbee. Carosin is cheery but distant, Rodney and Sandra laugh and pretend to tackle each other.

Geoffrey holds the painting up to see.

It catches Carosin's eye from a distance. Utter shock. Her breath catches in her throat.

Her hand goes to her mouth. Sandra and Rodney see Geoffrey and pause, they stop laughing but are still smiling.

\section{SANDRA}

That's beautiful Geoffrey!

Sandra waves him to bring it closer.

Carosin sputters, turns to her parents to explain.

Unaware, Rodney and Sandra stare at it, inspect it.

RODNEY

Very nice!

Carosin, quietly - 
CAROSIN

That's her...

Rodney and Sandra look puzzled. Geoffrey lowers the painting onto his feet, balances it and looks down.

He looks to Carosin. He gives a thumbs up.

INT. MOTEL ROOM, CANTERBURY - - AFTERNOON .

Carosin is packing her bag again. Geoffrey is pretending to read a comic, glancing over at her often.

She notices. She stops packing, crosses to him and hugs him tightly.

INT. AIRPORT, CHRISTCHURCH. - AFTERNOON.

Carosin stands, facing Rodney, Sandra and Geoffrey.

CAROSIN

I'll call this time. Really I will.

SANDRA

Don't be gone too long either. We really did miss you.

Carosin believes it now. She tries not to cry, laughing and fanning her eyes.

Oh! Gross!

CAROSIN

She sniffs thickly. Yuck.

Rodney starts a sort of lame cheer and they collapse into a group hug. Sandra wiggles her bum and cheers too. Carosin laughs.

They break apart.

CAROSIN
I have got to go!

Everyone nods. Geoffrey waves energetically even though they're a meter apart.

$$
\text { You dork. }
$$$$
\text { CAROSIN }
$$

She smushes right down his face again. Geoffrey reacts by licking her hand as she does. She shakes the liquid off dramatically, play-acting disgust. Geoffrey grins. 
Carosin looks to her parents -

$$
\begin{aligned}
& \text { CAROSIN } \\
& \text { Thankyou. Really. }
\end{aligned}
$$

Sandra is staring at Carosin's hands. Her face is a picture of bewildered confusion.

\section{SANDRA}

Carosin your hands!

Carosin nods and speaks quietly -

CAROSIN

I fixed them.

Sandra's eyes well. She touches Carosin's arm.

SANDRA

What do you mean?

CAROSIN

I have to go Mum, I REALLY have to go.

Rodney nods .

Carosin turns to leave.

SANDRA

I really didn't mind Caro... the staining...

I know.

CAROSIN

Carosin smiles and walks away, towards Security.

The others wave, Sandra calls out, highly emotional -

I love you!

SANDRA

Carosin smiles, soaking up the warmth. She turns away and balls up her hands. She whispers to herself -

I love me too.

CAROSIN

INT. AEROPLANE CABIN. - EVENING.

Carosin sits awake while all the other passengers sleep in the dimmed cabin. 
By the light of the golden overhead lamp she attempts to do henna over her arms with a small tube.

It is not perfect, but Carosin is focused intently, determined.

INT. HALLWAY OUTSIDE DOREEN'S APARTMENT, KL. - MORNING.

Ruchika and Doreen scuttle out of their door, dressed in wedding attire, nervously whispering and gesturing to each other to be silent.

INT. AABIDAH'S BEDROOM, KUALA LUMPUR. - MORNING.

Aabidah hears people in the hallway. She is energized.

INT. LIVING ROOM, AABIDAH'S APARTMENT, KL. - MORNING.

She grabs a jacket and her satchel and, listening at the door, waits for them to be half way down the stairs.

INT. HALLWAY OUTSIDE AABIDAH'S APARTMENT, KL. - MORNING.

Aabidah opens the door an inch. Silence. Two inches. Silence.

She runs into the hall and down the stairs, even jumping down a few steps.

EXT. STREET, CENTRAL CITY, KUALA LUMPUR. - MORNING.

Aabidah follows them at a covert distance, playing spy. She treads with light steps, peering around corners and glancing around to make sure she isn't being followed.

She shakes her head. Nonsense.

INT. KUALA LUMPUR CUSTOMS, KL AIRPORT, KL. - MORNING.

Carosin shakes her head, frustrated with queuing.

EXT. TAXI STAND OUTSIDE KUALA LUMPUR AIRPORT, KL. - MORNING. Carosin hails a taxi, thankful and sweaty. 
INT. COMMUNITY HALL, CENTRAL KUALA LUMPUR. - MORNING.

Ruchika finishes decorating the space to look more like a mosque with panels and fabrics and cushions with Doreen's soon-to-be wife, also in a beautiful dress.

INT. TAXI, DRIVING AWAY FROM KL AIRPORT. - MORNING.

Carosin, backpack still on in the back of the taxi, hurriedly find a folded 'sender's address' label, ripped from the back of the package Ruchika sent her. She shows it to the driver, who nods. Carosin smiles her relief, looks out the window and fist pumps. The driver observes her in the rear view mirror, incredulous. Carosin does not care, she is joyful.

INT. COMMUNITY HALL, CENTRAL KUALA LUMPUR. - MORNING.

Ruchika smooths seat cushions for Doreen's wedding thrones.

EXT. COMMUNITY HALL, CENTRAL KUALA LUMPUR. - MORNING.

A tall and severe woman acts as security for the wedding. Her role is serious but she is also obviously revelling in her newfound power and status.

Aabidah approaches and is stopped physically.

$$
\begin{gathered}
\text { SECURITY } \\
\text { Your kind don't worship here. }
\end{gathered}
$$

Aabidah is puzzled, offended. The SECURITY WOMAN leans forward conspiratorially -

\section{Breeders.}

\section{SECURITY}

She laughs harshly. Aabidah rolls her eyes and tries to enter again. She is stopped again, and backs away towards the curb.

EXT. COMMUNITY HALL, CENTRAL KUALA LUMPUR. - MORNING.

Dozens of guests, mostly queer and apparently all friends of the security person, arrive and enter. Aabidah tries to sneak through in several groups but is halted every time. She scowls energetically.

CUT TO: 
Later, things are getting desperate. A taxi pulls up. Aabidah looks to it.

EXT. AABIDAH'S APARTMENT, KUALA LUMPUR. - MORNING.

Carosin stands outside Ruchika's apartment, nervous.

She rereads the address, rereads the door, rereads the address, rereads the door.

She knocks. She does a nervous jittery dance. She wipes her face. She knocks again.

Zikri comes running up the stairs. He is sweaty and frantic. Carosin turns, surprised.

Where is she?

ZIKRI (BAHASA MELAYU)

Carosin looks befuddled.

ZIKRI

Sorry. Ruchika? You know Ruchika?

Carosin nods.

ZIKRI
She's at a wedding?

Carosin shrugs. Zikri, still panting -

ZIKRI

A wedding Doreen is at?!

Carosin shrugs again. Zikri, frustrated, turns and makes his way down the stairs at a jog.

Nervous and flustered, Carosin panics -

CAROSIN

Can I come with? ...with you?

Zikri pauses, shrugs.

ZIKRI

I can't stop you.

Carosin smiles and jogs to catch up with him. She offers him a high five when she levels with him. He leaves her hanging.

Okay!

CAROSIN 
She fist pumps the air, they descend the stairs together.

INT. TAXI, DRIVING THROUGH CENTRAL KUALA LUMPUR. - MORNING.

Zikri tells the driver the address in Bahasa Melayu. Carosin looks nervous.

INT. COMMUNITY HALL, CENTRAL KUALA LUMPUR. - MIDDAY.

Ruchika stares lovingly as Doreen and her fiancée enter. The ceremony is beginning.

EXT. COMMUNITY HALL, CENTRAL KUALA LUMPUR. - MIDDAY.

Aabidah is nervously shuffling. The guard glowers smugly down at her.

Carosin and Zikri's taxi pulls up. Carosin starts up the road, having paid. Zikri runs out after her and overtakes Carosin to get to the door first.

Zikri is halted by the guard woman. Aabidah beams at him.

$$
\text { ZIKRI (BAHASA MELAYU) }
$$

What? Let me in! Am I too late?

He turns to Aabidah -

\section{ZIKRI (BAHASA MELAYU)}

Is my wife married to that hippy?

The guard stays serious with a hint of incredulity. Carosin's face shows panic. She looks between the guard and Zikri.

Zikri is exhausted and heart broken, utterly frustrated -

$$
\begin{aligned}
& \text { ZIKRI } \\
& \text { So this is how it is?! I'm losing } \\
& \text { my wife and baby to a dyke?! }
\end{aligned}
$$

Aabidah takes a deep breath, and takes Carosin's hand.

Zikri is appalled, puzzling. Carosin is taken aback but is also terrified of being culturally insensitive, or punched, so she just goes with it.

The security woman, impressed, lets them enter.

Zikri steps forward, and is rebuffed again. He is outraged and storms in a circle. A group of men walk past in the street, muttering and playing up. 
The security woman shifts her weight, looking confident and unconcerned.

INT. COMMUNITY HALL, CENTRAL KUALA LUMPUR. - MIDDAY.

Carosin and Aabidah enter the ceremony silently. Aabidah

strides to where the brides sit. Carosin panics. Doreen looks terrified, focused on Aabidah.

Aabidah, in a measured and elegant movement, places her hand over her heart and closes her eyes, smiling. She opens her eyes. Doreen and Maria smile their thanks, a little bewildered. They proceed. Aabidah, smiling broadly, walks to the back of the hall and sits in the furthest row.

Doreen sees Carosin at the back of the hall. Her mouth falls open. She snaps it closed again, nods a small greeting to her.

Carosin exhales, and looks about the room. She catches a glimpse of Ruchika in the front row. A long moment of simply watching.

Carosin drops her large backpack and walks, terrified, the very long way round to the row where Ruchika sits.

The affirmation begins. A lot of those in the crowd exclaim or cheer as this is not a formal event, but it is definitely serious.

Adrenaline pumping, Carosin silently takes a seat beside Ruchika. The room falls silent as the crowd settle and the speech becomes more formal.

Ruchika silently takes Carosin's hand.

Carosin looks to her.

Ruchika smiles, facing forward, a tear rolling down her cheek.

Carosin, looking forward too, smiles.

Their interwoven fingers tighten. They hold.

MUSIC .

We see a series of short glimpses, showing hands and occasional bodily context, but never the characters' eyes. Carosin kissing Ruchika's hand while another one balances on her growing pregnant belly. 
A pinky promise between them.

A hand squeezed through labour pains, the sound of groaning. Carosin and Ruchika each holding one hand of a baby with a blue wine stain on it's arm.

Carosin's arms, out the window of a moving car, pulling the fingers at a city flying past, Ruchika pulling Carosin's hands back in to the car. Don't be ridiculous.

Carosin attempting henna on Ruchika's arm as Ruchika elegantly does henna on Carosin's.

Ruchika painting an image of Carosin's hands and a small child's hand. In the image they are covered in paint.

Ruchika tucking a hair behind Carosin's ear, Carosin smiles. Carosin wiping a tear from under Ruchika's eye.

A victory high five with a hand hold in mid-air, latticed fingers. We did it!

A 'Why don't you get this' exasperated hand gesture.

A medical pulse clip on Carosin's fingertip.

Ruchika hands tickling their child's torso.

Ruchika and Carosin cooking a dinner and tasting the mix.

Carosin's hand pressed over her mouth, in the bathroom, gasping back desperate tears.

Carosin going for the last piece of cake and being batted away by Ruchika. The child's hand taking it instead.

Ruchika's hands in prayer on her mat.

Carosin holding Ruchika's wrists as Ruchika tries to hit her. A reconciliatory hand on hand across a wide glass table. Carosin and Ruchika having an energetic thumb war. Carosin slamming a fist down onto a kitchen table. Carosin and Ruchika holding hands. Carosin's hands, shaking and praying, begging desperately. The sounds of whimpered crying.

Holding hands. 
Ruchika doing a stick and poke tattoo on Carosin's arm of an ornate henna-style flower, the centre of the flower being one of Carosin's small perfectly circular cigarette burns.

Holding hands.

Two hands, pretending to be little people with fingers for legs, running towards each other.

They go SPLAT when they meet.

END. 